\title{
Practices in Software Outsourcing Partnership: Systematic Literature Review Protocol with Analysis
}

\author{
Sikandar Ali ${ }^{1} 2^{*}$, Li Hongqi1 ${ }^{1}$, Siffat Ullah Khan ${ }^{3}$, Yang Zhongguo ${ }^{1}$ \\ ${ }^{1}$ Beijing Key Lab of Petroleum and Data Mining, Department of Computer, China University of Petroleum, \\ Beijing 102249, China. \\ 2 Department of Computer and Software Technology, University of Swat, Pakistan. \\ ${ }^{3}$ Department of Computer Science \& IT, University of Malakand, Lower Dir, Pakistan. \\ * Corresponding author. Tel. +8615611818230;+923339498398; email: hqsikandar@yahoo.com \\ Manuscript submitted August 27, 2017; accepted November 22, 2017. \\ doi: $10.17706 /$ jcp.13.7.839-861
}

\begin{abstract}
Software outsourcing partnership (SOP) is a type of client-vendor cooperative relationship for achieving mutually beneficial goals and is totally based on mutual trust and commitment. Usually a fruitful outsourcing association may possibly convert to outsourcing partnership. The development of SOP depends on the employment of various factors like 'mutual inter-dependence and shared values', 'organizational proximity', 'mutual trust', 'effective and timely communication' and 'quality production'. The objective of the research is to find out practices through Systematic literature review (SLR). These practices will be used to implement critical factors in SOP. We have identified a list of 142 'practices' for 14 critical factors through SLR methods. This paper presents preliminary frequency analysis on practices in SOP. We have distributed studies found on publication venue, organization size, collaboration model used, study quality and year. Further, we have listed top venues and authors. The results might benefit the researcher interested in knowing about who involved in outsourcing partnership. Our outcomes can help practitioners working on outsourcing collaboration in the software development industry. They can determine from the results of the study where to outsource and which are the emerging countries in software outsourcing.
\end{abstract}

Key words: Systematic literature review, software outsourcing, practices/solutions, partnership.

\section{Introduction}

Collaborative relations such as outsourcing partnership over passing the traditional organizational limits and are an essential measure of today's trade success. Organization that struggles for competitive advantages via mutual aid creates new inter-organizational as well as intra-organizational arrangements and nets. Organizational relations in these nets go yonder the old-style order and supply sequence trades. In this type of relation, everything like investments, risks, profits and loss of joint struggles are distributed amongst allies. Long lasting corporate relationships are made based on reciprocal trust. Collaboration generally helps in reducing the expenditures of attaining and applying appropriate expertise and competencies required for an efficient professional development. Collaborative associations are typically called associations, alliances, coalitions, joint ventures or partnerships [1]-[3].

In the course of the earlier two decades, partnerships have emerged is one of the key stratagems for growing organization, in order to stay in the market competition [4]. Partnership is a cooperative association among autonomous organization(s). Partnerships might benefit organization to persist in 
competition by increasing efficiencies [4], joining new markets [5], giving new produces and gain access to new resources pool [6].

Due to big economic changes, globalization, antagonism from low remuneration unindustrialized countries, and improvements in information technology (IT). From 1980 onwards various types of business networks have been shaped such as strategic networks, multi-vendor contracts, different kinds of association, alliances, coalition, joint ventures, and partnership etc [7], [8]. Obliviously different kinds of companies having not the same kind of needs, consequently considerably many kinds of associations are obligatory [9]. Software development (SD) companies now use a widespread diversity of methods to source SD work; they outsource, develop in-house, broaden in-house competence through acquirements, and shape joint ventures or partnerships with oversea organizations [9].

According to Kishore [10], outsourcing associations can be branded into four brands. These are ordered as 1st Support, 2nd alignment, 3rd reliance and 4th alliance. A collaborative relationship with low control and high trust in executing the contract is term as an alliance. Outsourcing partnership is one type of an alliance [11]. Outsourcing partnership is a type of business alliance that is a combination of both partnering and outsourcing thus thoughtful understanding of both term is obligatory to understand the collective terms outsourcing partnership. Kinnula et al. [12], express outsourcing as "The process of transferring the responsibility for a specific business function from an employee group to a non-employee group".

Software Outsourcing partnership (SOP) is a relation for a long time based on the renegotiations of mutual adjusted task and commitment that supersede the stated contractual terms and conditions as specified in the opening stage of the alliance [13]. It is flexible, long term and based on sharing of risks, benefits, future goals and visions. In practice, only a fruitful outsourcing relationship is a candidate for promotion to outsourcing partnership [10]. It cannot be instantly developed, but rather, it shapes with the passage of time [12]. A key difference in SOP and ordinary outsourcing is in their level of depth; SOP is a deeper relationship [8]. A relationship is said to be SOP, where the parties share confidential information about future plans, work together, combine resources, share risks and benefits, and make joint decisions to achieve mutual advantageous results [14]. Outsourcing partnership is a good tool to overcome technological uncertainty, because it can effectively be dealt with uncertainty, by sharing information of unexpected events in developments [15]. In joint venture, literature partnerships are relationships with certain characteristics to build trust [16]. The main difference between partnership and contractual relationship is that in partnership relationship the stress is given on trust and achieving general business goals while in a contractual relationship the stress is given on the obligation of a formal contract and on achieving specific business goals. In summary, partnerships are about relationships, not contracts [16].

In management manuscripts, the partnership has been explored extensively [17]. For example, the collaboration between firms has examined in the marketing discipline [18], partnership between producers and suppliers [19], manufacturers and sales agents [20], buyers and sellers [21] as well as auditors and clients [22]. While in computer literature empirical literature survey on the partnership relationship started to grow after 2000 in the Europe, America, and Asia. For the present study, a partnership is a mutually beneficial, unceasing and long lasting relationship, in which future plans, visions, and confidential information are shared with partner organizations willingly and proactively in demand to help each other in focusing on their capitals in the correct track [23].

According to Kedia and Lahiri [23], the organizational business related work is currently endorsing extensive outsourcing of production work from developed nations such as the United State to numerous overseas outsourcee such as China, India, Ireland, Malaysia, Ukraine, Philippines, Russia, Pakistan and Latin America etc. This increase occurs because to stay alive in the current highly competitive industrial setting, a lot of new organizations involved in global outsourcing of product and services. Regardless the growths of 
international collaboration, the studies of partnerships between client and their foreign vendor have not attained sufficient consideration in the academic literature.

In order to identify SOP solution/practices for the execution of various Success Factors (SFs) from the perspective of a vendor, we have verbalized the following research question (RQ).

RQ1. What are the solution/practices, as reported in the literature for the employment of various factors in SOP from vendor's perspective?

\section{Background}

In literature, outsourcing partnership is divided into three diverse perspectives, (1) economic, (2) social and (3) strategic management [24]. The first one is based on two theories i.e agency theory and transaction cost theory. It looks at governance, coordination, productivity and financial connections between firms [25]. But it does not focus on reasons for outsourcing besides cost efficiency [24]. Social perspective is also based on two theories i.e relational exchange and social exchange, it emphases on the existence of trustful client-vendor relationship [24]. It is distinguished from the others by the fact that it focuses on the issues such as mutual trust, equity, and cooperation. Further, there are communal goals and a written bond of mutual sureties between the parties [26]. Here the formal contract exists but it is not enough alone for the success of outsourcing arrangements [27]. In this perspective dissolution or extension of a relationship is grounded on the bi-directional agreement [25]. The third and last one is based on the theory of resource dependency, it explains how firms achieve desired goals by implementing outsourcing paradigm [24]. However, it does not consider the issue of relationship management [24]. Previous research [28] classify the organizational relationship into two types:

A. Transactional style: This type of relationship is built through a proper agreement, here the procedures are well stated and in the case of disappointment to deliver the said services by any party is set on through a court case or forfeit as defined in the bond.

B. Partnership style: It is based on sharing of risk and benefit. This type of relationship is view as a sequence of connections without a fixed endpoint, it requires to establish a way for monitoring and executing its processes [29].

From partnership view point, there are dual outsourcing types.

A. Service outsourcing: Here, system integration services are provided without asset transfer.

B. Asset outsourcing: It involves shifting of people hardware, and software to partner site [30].

\subsection{Existing Literature}

A numeral investigators have shed light on some of the problem of SOP, such as Kedia and Lahiri [23], li [31], Lai [32] roses et al. [33], Dwyer [21], Yilitalo [34] kinnula [12], Ellram [35], Tuten and Urban [36], Kinnula and Juntunen [37], Hussein [38], Flemming and Low [39], Garousi [40], Bocij [41], Piltan et al. [42]. Summary of few of these are presented as follow:

Recently published studies by Lai [32], on the factors affecting partnership quality between service receiver and providers in outsourcing ventures. It also shed lights on the connection flanked by the quality of partnership in outsourcing and the ultimate attainment of outsourcing benefits. The results show that factors such as shared knowledge positive effect on shared benefits, organizational linkage positive affect commitment and predisposition, bi-directional dependency positive effect on mutual benefits, commitment and predisposition, and commitment have positive effect on outsourcing success.

Garousi et al. [40], conduct a study to find a list of practices for arrangement and steering collaborative projects. Through thematic exploration, they acknowledged ten risk factors and seventeen solution groups. A notable findings of the study was the indication of best solution i.e the most common ones ensure management meeting, the requisite for a supporter, be agile throughout the partnership, and shifting of the 
investigator to the industrial environment.

Developing a fruitful long lasting cooperative correlation among two diverse organizations appears to be more complicated and demanding as generally expected. According to Dwyer [21], development of partnership is a multi-dimensional practice in which psychosocial, economic and legitimate procedures are concurrently proceeding. Common objectives and directions, better communication, reciprocal trust and assurance and partner compatibility are the constituent elements of a fruitful partnership [34]. The main motives for outsourcing partnership are cost savings, increased flexibility, bi-directional decision making, acquiring to professional expertise, better-quality of service, free management time when there is lack of resources, and improved financial control [41].

\subsection{Why do Partnerships Fail?}

Engaging in partnership with other firms might improve firms' enactment. Conversely, a partnership is not a threat free trade. According to the literature [42]-[45] partnership has a high disappointment rate. A research conducted by Piltan et al. [42] in 2007-08, conveyed that above $80 \%$ of CEOs said that partnerships were the core source of producing nearly $26 \%$ of their organization incomes. Still, partnerships have high failure proportions. Cost saving is an attractive factor (outsourcing may save $50 \%$ of the development cost or even more), but what if the budget will be wasted (you get a software with very ruthless quality) [46]. Bamford et al. [3] and piltan et al. [42], reports the failure ratio of partnerships from $30 \%$ to $70 \%$. For that reason, observing the performance of a partnership and assessing the elements that have a negative impact on its performance is crucial. Information sharing, joint decision taking panel, risk and reward sharing, trust, commitment, and relationship specific assets are recognized as the foremost factors that affect the performance of an enduring partnership[42].

According to Tuten and Urban [36], the reasons are somehow certainly connected to the lack of putting into practice of SFs like, lack of upfront planning, pitiable communication, lack of relationship management, lack of trust and diverse goals and unsatisfactory performance signs indication. Various other reported causes by other scholar are changing of partner at the middle of the relationship and the corporate related causes of an individual or mutually [35].

\section{Research Method}

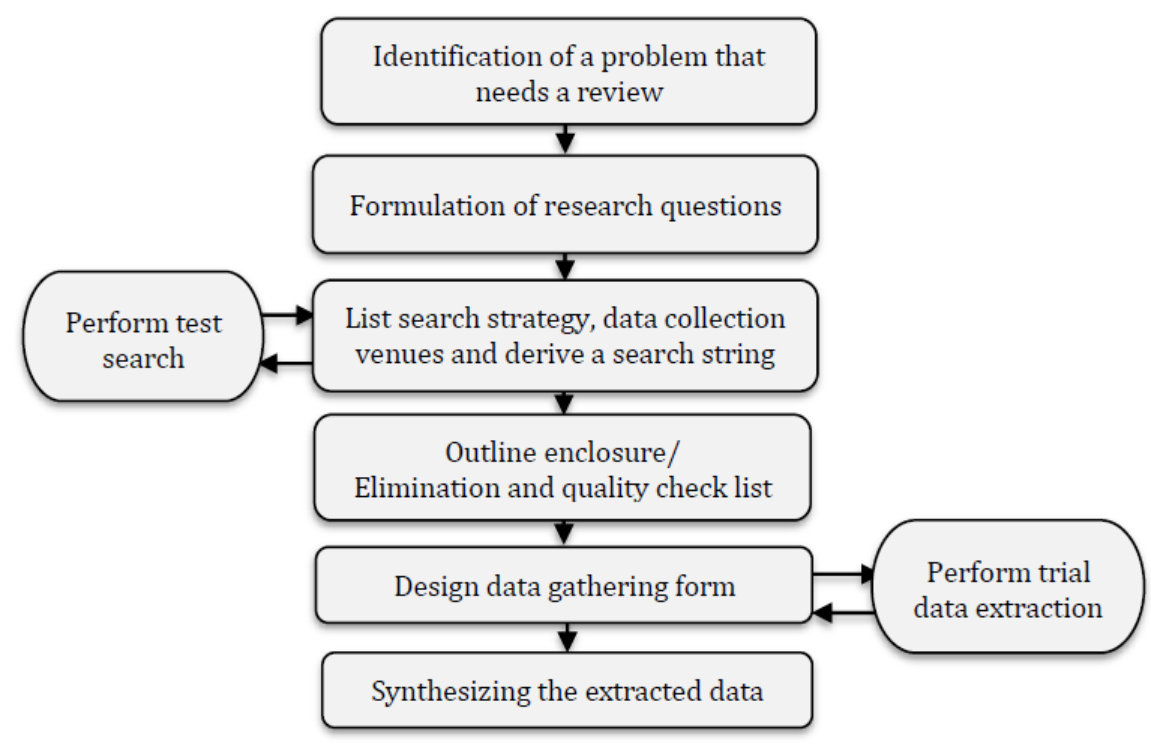

Fig. 1. Development process for the SLR protocol. 
Systematic Literature review (SLR) [47] is chosen as a method for data gathering. It is an unbiased method of data collection on the basis of pre-defined research queries. It helps to collect facts from the included primary studies in a systematic way. It is also used as a main methodology for our preceding study. The main steps of the methodology are shown in Fig. 1.

\subsection{SLR Protocol Development}

To increase thoroughness, repeatability and to reduce the researcher biasness in a review, proceeding to the actual review process, we have settled a review plan called protocol. The protocol proposes the review procedures and plans by cataloging the particulars of several approaches for executing the systematic review [47]. Fig. 1 Outline the protocol development process. The first two steps have already mentioned in introduction. Detailed of the next steps is given below.

\subsection{Search Strategy}

\subsubsection{Search terms for automatic search}

One of the main challenges of performing an automatic search in the field under study is to find a relevant study in the domain, is the lack of standard and well-defined terms. Due to this problem and to avoid missing any relevant paper in the automatic search, we prefer to use a more generic search string. We included a wider number of papers in the primary results. Later, we filter out the irrelevant studies to get the final papers for data extraction purpose. We used the research questions and a stepwise strategy to obtain the search terms; the strategy is as follows:

- Identify intervention, population, and outcome on the basis of research questions.

- Identify the main term and construct search term from it.

- Find the synonyms and alternative spellings for each main term.

-Validate the terms and synonyms in any related paper.

- Combine these terms using Boolean OR/AND operators.

\subsubsection{Search the literature}

A manual search was conducted for the determination of resources to be searched. In this phase we initially develop a trial search string which was used in different digital libraries during the automatic search. The available different digital libraries are

-ACM-[acm.org].

- IEEExplore-[ieeexplore.ieee.org].

- CiteSeer-[citeseer.ist.psu.edu].

-ScienceDirect-[sciencedirect.com].

- GoogleScholar[scholar.google.com].

- SpringerLink[springerlink.com].

We have used this search string as a test search string. ((Solutions OR "lessons learned" OR practices OR Advice OR "best practice") AND (Partnership OR "Outsourcing partnership") AND ("Software outsourcing" OR "IT outsourcing" OR "IS outsourcing") AND ("Success Factors" OR Factors OR CSFs). Table 4, presented the final list of resources to be searched. The selections of these resources are based on our preceding SLRs [13], [48].

\subsection{Literature Selection Criteria}

\subsubsection{Inclusion criteria /Exclusion criteria}

The criterion is publicized in Table 1. 
Table 1. Enclosure Criteria/Elimination Criteria

Papers that describe practices or solutions or advice or lesson learned for software outsourcing partnership

Papers that are written in English only and full text is available

Papers those are not related to the research questions

Paper that does not follow inclusion criteria

\subsubsection{Study quality check list}

Table 2. Publication Quality Evaluation Check List

\begin{tabular}{lc}
\hline \hline \multicolumn{1}{c}{ Criteria } & Code \\
\hline $\begin{array}{l}\text { Is it clear in what way the practices were identified for the proper implementation of } \\
\text { critical success factors in software outsourcing partnership? }\end{array}$ & $1,2,3$ or 4 \\
Has there adequate data to support the results? & $1,2,3$ or 4 \\
$\begin{array}{l}\text { Is it clear how solution/practices were measured in SOP relationship? } \\
\begin{array}{l}\text { Is the researcher giving the impression to report optimistic results larger than adverse } \\
\text { results? }\end{array}\end{array}$ & $1,2,3$ or 4 \\
\hline \hline
\end{tabular}

The quality check will be performed at last using criterion given in Table 3. For each paper, the check list will be coded as Yes $=1$, partially $=2, \mathrm{NA}=3, \mathrm{No}=4$.

\subsubsection{Study quality classes}

1. Criteria for A-quality papers:

In this category we list those papers which fulfill the following criteria:

- Paper published in impact factor Journal

- Having sample size of the following condition

a) Case Study $\geq 3$, b) Interviews $\geq 12$

b) Survey $\geq 50$, d) Literature Review $\geq 50$

\section{Criteria for B-quality papers:}

In this category we list those papers which fulfill the following criteria:

- Paper published in well-reputed conference

- Having sample size of the following condition

a) Case Study $=2$, b) Interviews: $\geq$ 5and $\leq 11$

b) Survey: $\geq 30$ and $\leq 49$, d) Literature Review: $\geq 30$ and $\leq 49$

\section{Criteria for C-Quality Papers:}

In this category we list those papers which fulfill the following criteria's:

- Experienced reports/ articles, published in less reputed venues (Journal, Conference)

- Having sample size of the following condition

a) Case Study: 1 , Interviews $\leq 5$, b) Survey: $\geq 1$ and $\leq 29$

b) Literature Review: $\geq 1$ and $\leq 29$.

Classification based on this quality criterion is given in Table 6 .

\subsection{Data Extraction}

\subsubsection{Data extraction forms}

What data to be extracted from each selected study are shown in Table 3. Data extraction processes are pictorial in the Fig. 2. The first two authors work as a primary investigator while the next two authors are the secondary investigator. Each primary review will independently review all papers and then compares the results obtained with each other. In the case of disagreement will approach the secondary reviewers. 
Table 3. Data Extracted From

\begin{tabular}{|c|c|c|}
\hline \# & Note & Description \\
\hline N1 & Author(s) & Author(s) of the included studies in the SLR. \\
\hline $\mathrm{N} 2$ & Title & Title of the paper included studies in the SLR. \\
\hline N3 & Year & Year in which the study was published? \\
\hline N4 & Venue & Publication category of the included article: For example Conference, Journal, etc. \\
\hline N5 & $\begin{array}{l}\text { Research } \\
\text { Methodology }\end{array}$ & $\begin{array}{l}\text { A kind of research methodology incorporated in the included article? It can be a case } \\
\text { study, experience report, etc. }\end{array}$ \\
\hline N6 & $\begin{array}{l}\text { Data Gathering } \\
\text { Method(s) }\end{array}$ & $\begin{array}{l}\text { A kind of research tool used for gathering data. For example Interview and } \\
\text { questionnaire survey, literature review etc. }\end{array}$ \\
\hline N7 & Citation count & It is the number of citation of the selected study on scholar.google.com. \\
\hline N8 & Study Perspective & The study Perspective is grouped into academic (e.g. student cases) and industry. \\
\hline N9 & Components of Analysis & The basic unit (e.g., organization or a project) that is under investigation in the study. \\
\hline N10 & Company Size & $\begin{array}{l}\text { It is the size of organization where the studied project is selected from or the } \\
\text { researcher carried out the study. }\end{array}$ \\
\hline N11 & SOP practice(s) & What software outsourcing partnership practice are reported in the study? \\
\hline N12 & SOP factors(s) & The success factors reported in the study. \\
\hline
\end{tabular}

\subsubsection{Data extraction process}

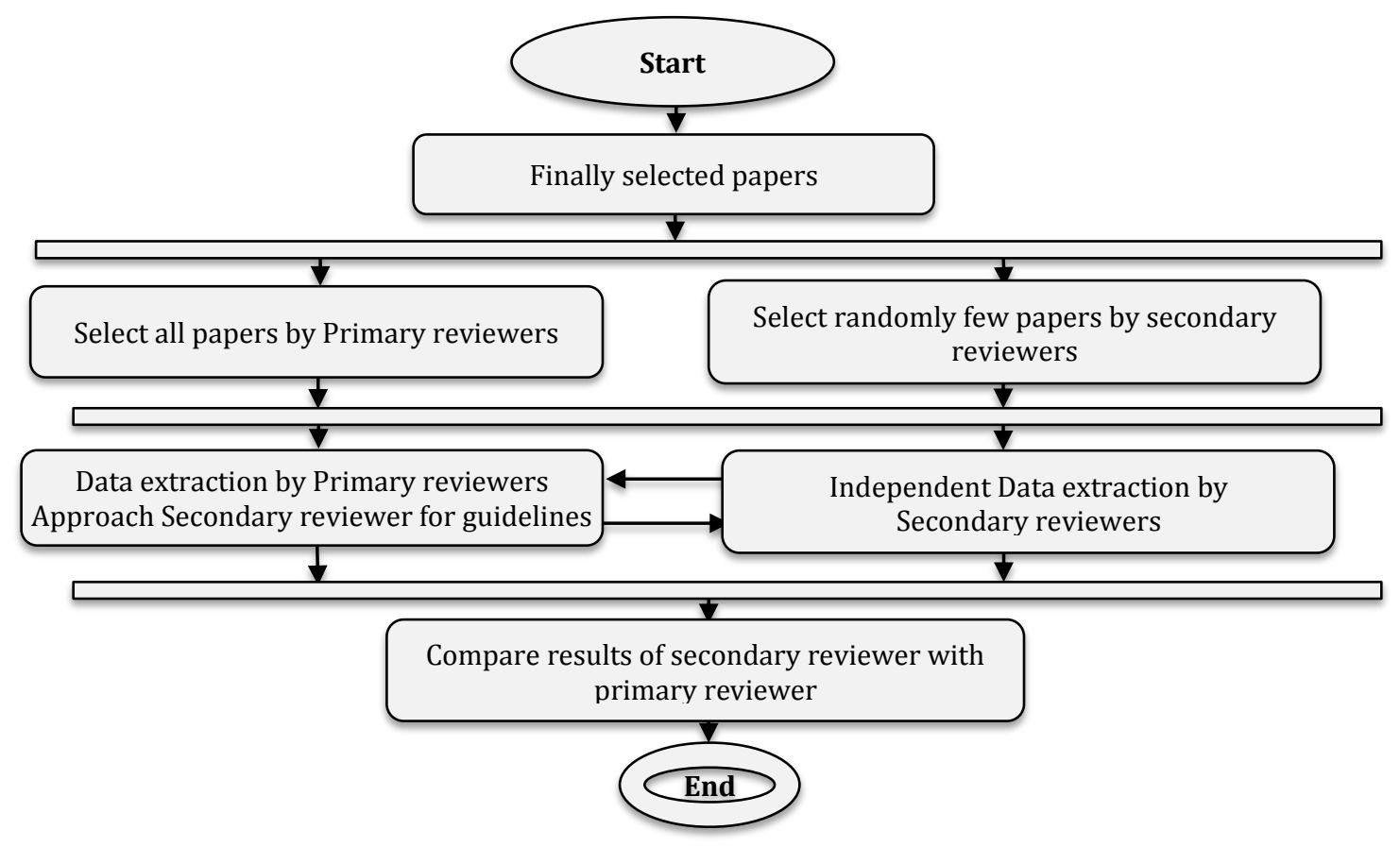

Fig. 2. Data extraction process.

Fig. 2 shows data extraction process. The first and last author work is primary reviewers while the $2^{\text {nd }}$ and third work is secondary reviewers

\subsection{Review Time Line}

The review took from Sept 2014 - December 2015 to complete.

\subsection{Protocol Authentication}


A first version was submitted for evaluation to an expert, as result of the review, he suggested some minor changes. The protocol was updated in light of the suggestion and then presented to the SERG (Software Engineering Research Group) at University of Malakand Pakistan for final comments and approval. Finally, it will be published as a research paper.

\section{Results}

Table 4. Study Sources and Results Found

\begin{tabular}{lccc}
\hline \hline \multicolumn{1}{c}{ Source } & $\begin{array}{c}\text { Total Results } \\
\text { retrieved }\end{array}$ & $\begin{array}{c}\text { Title abstract } \\
\text { based selection }\end{array}$ & $\begin{array}{c}\text { Selection on full } \\
\text { text readings }\end{array}$ \\
\hline IEEExplore & 261 & 85 & 15 \\
ACM & 772 & 90 & 10 \\
Science Direct & 711 & 85 & 28 \\
Google Scholar & 136 & 50 & 5 \\
CiteSeer & 320 & 30 & 3 \\
SpringerLink & 350 & 35 & 4 \\
Snow Balling & 40 & 20 & 10 \\
Total & $\mathbf{2 5 9 0}$ & $\mathbf{3 9 5}$ & $\mathbf{7 5}$ \\
\hline \hline
\end{tabular}

In this section, we report the results related to our research questions. By using search strategy of Section 3.2 on the pre-mentioned digital libraries, we found 2590 papers. The results of the primary and final selection are given in Table 4. Only 84 papers out of 2590 qualify the inclusion/exclusion criteria. Finally, the duplication was removed by excluded 09 papers from the final list of papers which repeated across the different digital library, and we get a final total of 75 papers as shown in Table 4 and Fig. 3.

\subsection{Distribution of Practices in Different Success Factors}

This section demonstrates the outcomes of the SLR i.e the practices/solutions for implementing SFs in SOP. Table 6 present SFs and the number of respective practices identified. In table 6 \# represent the paper number of a respective paper from which the practices were identified. We have identified 142 practices in total for 14 critical factors as shown in Table 5.

\subsection{Classification Based on Quality}

A paper is said to be very poor which not fulfill any quality criteria i.e A, B or C. Any studies which pass quality criteria- $\mathrm{C}$ were termed as Fair. An article which qualifies criteria-B is a candidate for good. While very good are those articles which pass criteria-A. From Table 6 it is clear that most of the included study was high quality paper.

Table 5. Number of Practices Found for Each CSF

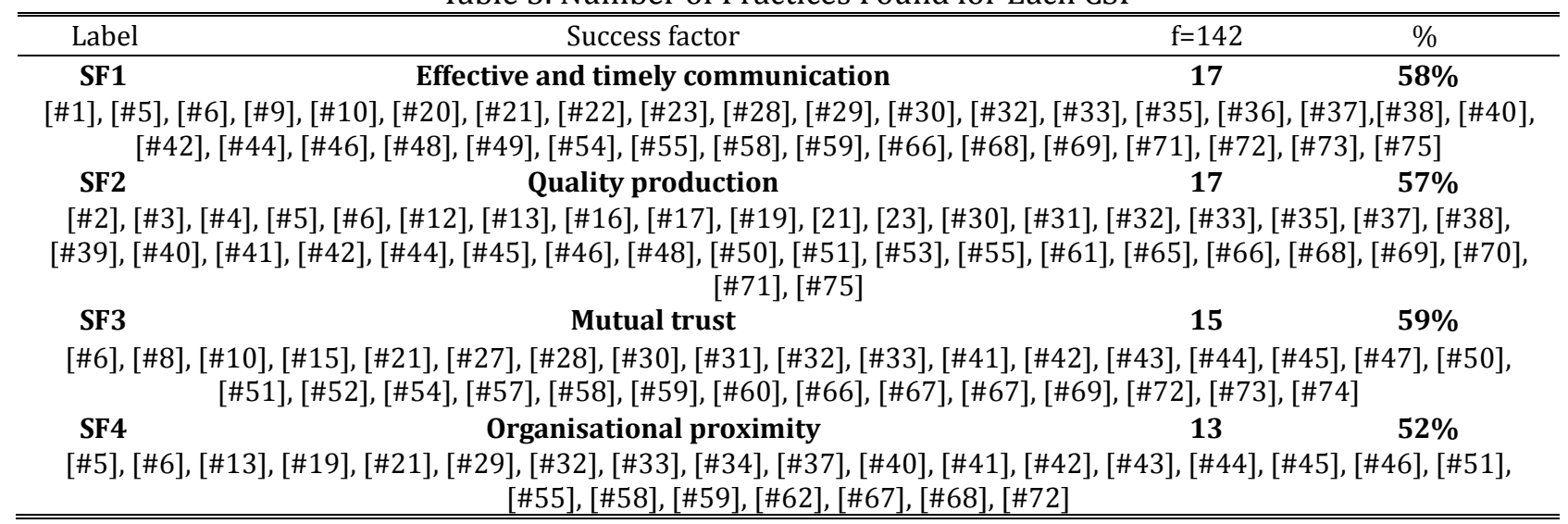




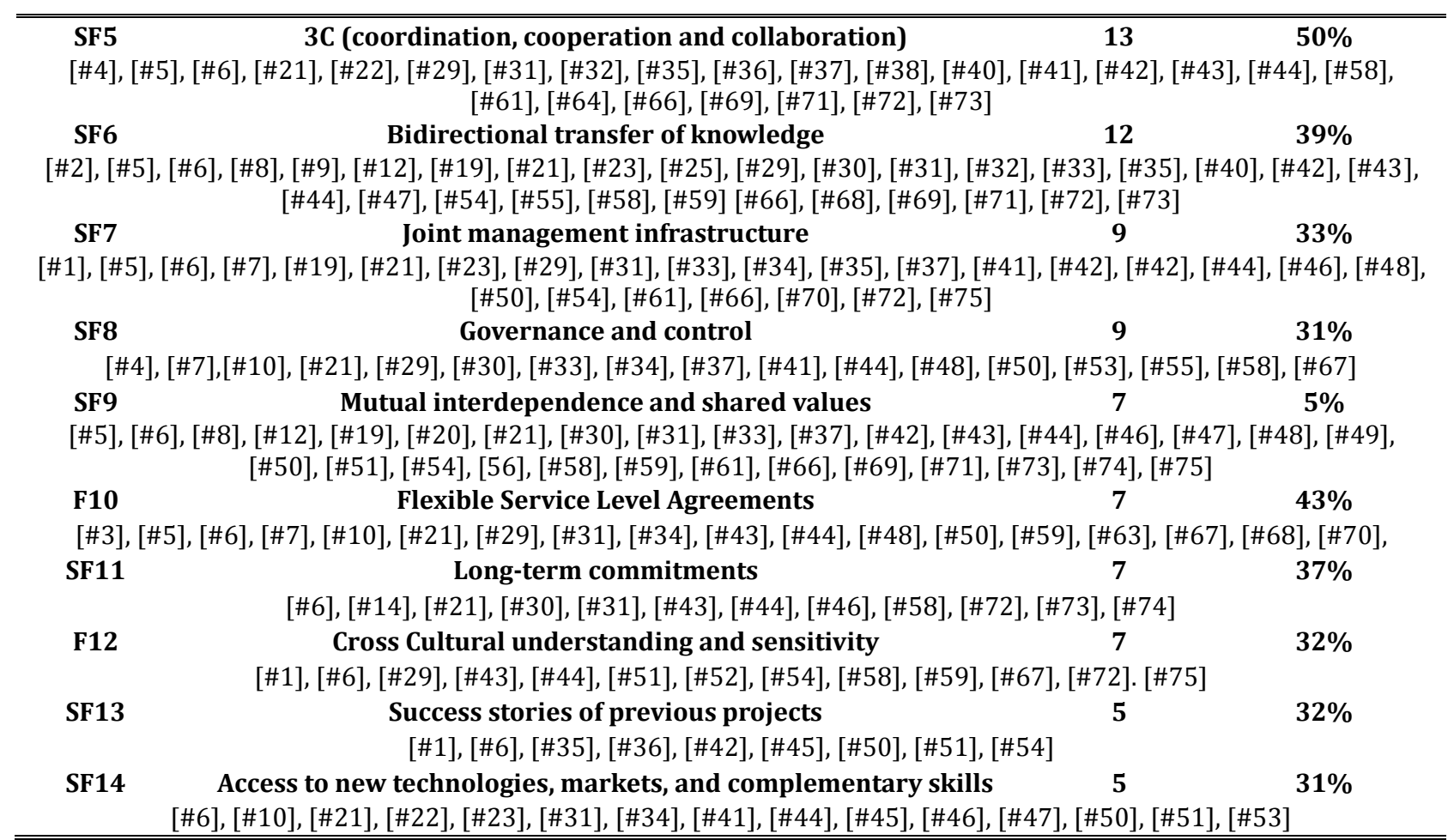

Table 6. Classification Based on Quality

\begin{tabular}{cccccc}
\hline \hline Quality Scale & Poor & Fair & Good & $\begin{array}{c}\text { Very } \\
\text { Good }\end{array}$ & Total \\
\hline \# of studies & 2 & 17 & 34 & 22 & 75 \\
Percentage & $2.67 \%$ & $22.67 \%$ & $45.33 \%$ & $29.33 \%$ & $100 \%$ \\
\hline \hline
\end{tabular}

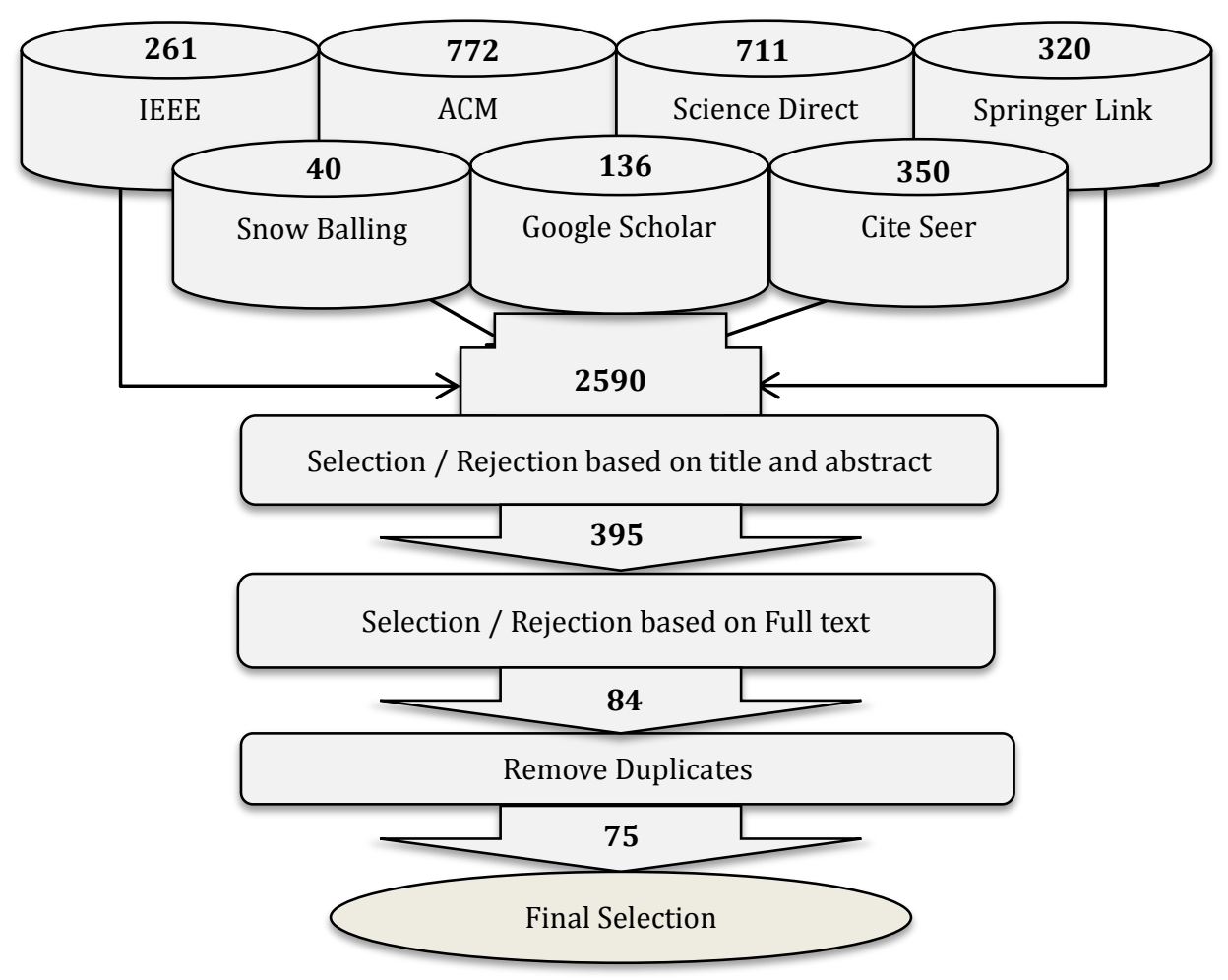

Fig. 3. Article selection process. 


\subsection{Data Gathering Methods}

We have assembled the finally included studies into seven study methodology, as shown in Table 7. These are frequently used sources for data collection in the software engineering discipline. Greatest numbers of the article have incorporated case study as an investigation methodology. These study mythologies were firstly recognized by the primary investigators during the data gathering practice. Though, secondary investigators have validated these study method. Khan et al. [48] also reported similar results for outsourcing.

Table 7. Studies Countries

\begin{tabular}{lc}
\hline \hline Methodology & Count \\
\hline 'Case studies' & 31 \\
'Experience report' & 4 \\
'Interviews' & 20 \\
'Survey' & 13 \\
'Literature review' & 2 \\
'Experimental study' & 1 \\
'Others' & 4 \\
Total & 75 \\
\hline \hline
\end{tabular}

\subsection{Countries Involved in SOP}

According to Venkatraman [49], with growth in offshore outsourcing, the research dispute has changed from how to outsource toward where to outsource. The finally included articles point out twenty-seven dissimilar republics from where firms have practice SOPS Table 8 shows countries with high counts are, Unites States (20 cases), India (12 cases), UK and China (10 cases each), Canada and Australia (06 cases each), Germany (04), and, Netherland and Finland (03 cases respectively). The US-Indian partnerships were described in most of the included studies in our SLR. The Asian republics such as Russia, India, China, and Malaysia, mostly take part as vendor partner in outsourcing partnership, as these are very widely held stations for outsourcing. Other cited countries are Korea, Singapore, Italy, Turkey, Pakistan, Brazil and New Zealand. Our study outcomes disclose that the European republics like Finland, France, Thailand, Norway, Denmark, Sweden, and Switzerland are emerging countries focusing on outsourcing partnership.

Table 8. Study Method Used

\begin{tabular}{lclclc}
\hline \hline Country & Count & Country & Count & Country & Count \\
\hline USA & 20 & Korea & 02 & Ukraine & 01 \\
India & 12 & Malaysia & 02 & Switzerland & 01 \\
China & 10 & Singapore & 02 & Lithuania & 01 \\
UK & 10 & Sweden & 02 & Pakistan & 01 \\
Canada & 06 & Denmark & 02 & Brazil & 01 \\
Australia & 06 & France & 02 & Italy & 01 \\
Germany & 04 & New Zealand & 02 & Turkey & 01 \\
Netherlands & 03 & Thailand & 01 & Norway & 01 \\
Finland & 03 & Ireland & 01 & Spain & 01 \\
\hline \hline
\end{tabular}

According to Jacob [50], offshore outsourcing is progressively affecting the EU-15 countries, both in the development and service area. According to 2013 Outsourcing in Europe report [51], Finland, Denmark, Sweden, Netherlands, Germany, Norway, Sweden, Spain, United Kingdom are new players from Europe. Access to particular expertise, tools, and knowledge might be a key factor for collaboration in outsourcing arrangements, which affects the offshore country choice for farm out services [51]. Ukraine and Lithuania 
are the new comers to outsourcing partnership. The results might benefit the researcher interested in knowing about who involved in outsourcing partnership. The outcomes will also help practitioners working on outsourcing collaboration in the SDO industry. They can determine from the results of the study, where to outsource and which are the emerging countries in software outsourcing.

\subsection{Collaboration Models}

Using the taxonomy proposed by Khan for outsourcing [48], we classified the papers according to collaboration models. Three type of collaboration model were identified:

- Onshore partnership -partner located in the same country.

- Nearshore partnership- partner from a different country but in the same continent.

- Offshore partnership- partner from an overseas country commonly located in a different continent.

In our SLR most of the partnerships formed are offshore (46\%) and Nearshore (32\%). Partnership formed in Europe is usually Nearshore. According to Butterworth [53], Finland, Spain, Norway, Sweden and the UK, these countries outsource less to offshore countries. Most offshore partnership is formed between US-India and US-China [54], [55].

\subsection{Size of Organization}

We classify the included articles based on the pre-arranged data as recommended by [52] into four classes: 1) Small: having 0 to 19 personnel), 2), Medium: having 20 to 199 personnel), 3) Large: 200 plus personnel) and 4) Mixed (combination of more than one category).

\section{Collaboration Models}

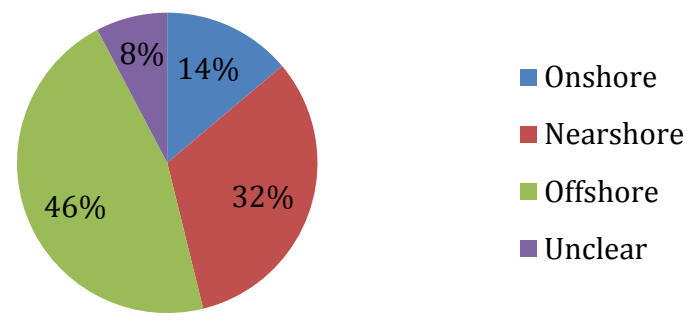

Fig. 4. Distribution of studies over collaboration model.

\section{Company size}

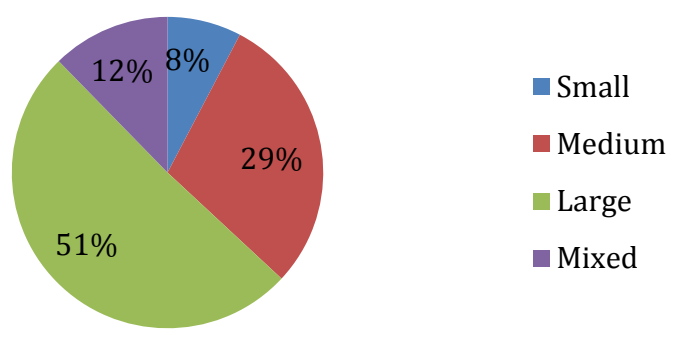

Fig. 5. Distribution of studies over organization size.

It is clear from Fig. 5. that most of the partnerships are formed in large size organization. The reason 
might be that partnership is not formed instantly but when the relation is matured it is converted to a partnership. Kinnula et al. [12], report that in demand to contract out work that is not mainly interrelated to organization fundamental business deeds, large software firms are migrating from ordinary outsourcing to partnership outsourcing.

\subsection{Chronological Observation}

Fig. 6 denotes the quantity of the included papers published in each year from 2001 to 2015. Though, we have not put any time limit in the search phase. Still, we found paper between 2001 and 2015(search year) only. Which shows that outsourcing partnership starts appearing in the literature in 21st century i.e in 2001.

It is worth noting that we perhaps may not catch any related paper available online in 2003. Fig. 6 shows that the number of studies on outsourcing partnership published per year has been increased since 2004 . We noticed that after 2004 only in 2011, the number of studies published per year is less than mean i.e 5 . $27(36.6 \%)$ papers where published during 1st half from 2001 to 2007 while 45(63.3\%) paper in the last 5 years from 2008 to 2014 excluding 2015 which is search year. It shows that outsourcing partnership are receiving increasing attention and interest from practitioners and researchers. But still the published paper per year is very low; it means the field is not much mature and more work need to be done. A similar view was presented in [53].

\subsection{Publication Classify by Venue}

Fig. 6 shows the categories of papers (i.e conferences or journals) involved in our SLR study. Journal is a widely held publishing venue with a count equal to 53 (i.e., 70.7\% papers). The rest of articles have been available in conferences (22 studies, 29.3\%). Table 9 and Table 10 shows the journals and conferences having frequencies $>2$ for our included studies with impact factor or edition number and their ERA rank.

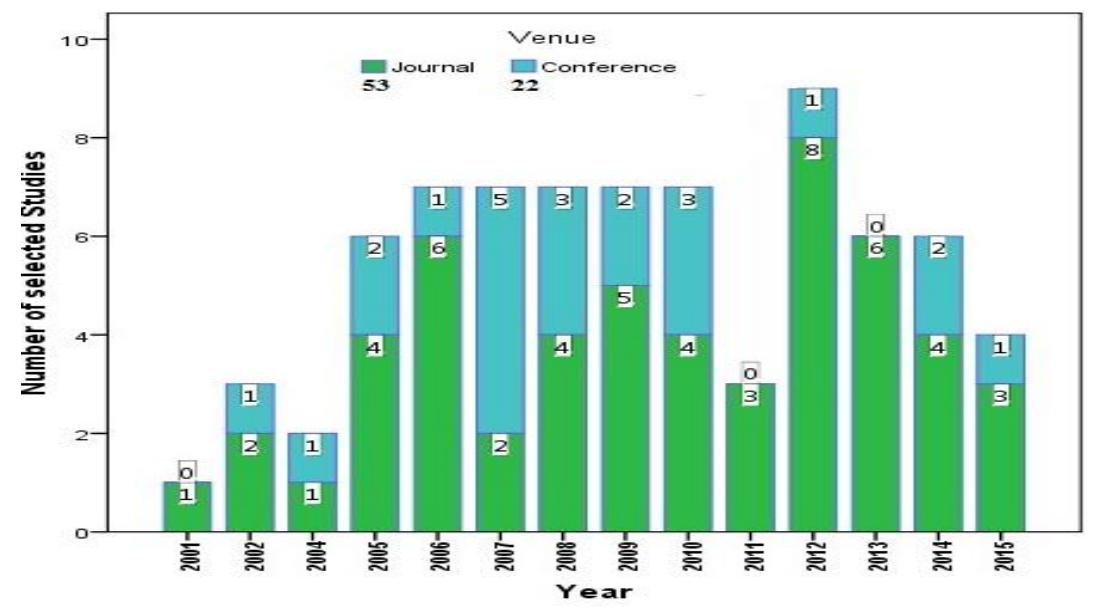

Fig. 6. Year wise distribution of studies over publication venues.

Table 9. Top Conferences in Our SLR Study

\begin{tabular}{clccc}
\hline \hline S.No & \multicolumn{1}{c}{ Name of Conference } & \# of studies & ERA rank & $\begin{array}{c}2017 \\
\text { Edition }\end{array}$ \\
\hline 1 & $\begin{array}{l}\text { 'Hawaii International Conference on System Sciences (HICSS)' } \\
\text { http://hicss.hawaii.edu/ } \\
\text { 'ICGSE- International Conference on Global Software Engineering' } \\
\text { http://icgse.org/ }\end{array}$ & 7 & A & $50^{\text {th }}$ \\
\hline \hline
\end{tabular}


Table 10. Top Journals in Our SLR Study

\begin{tabular}{|c|c|c|c|c|}
\hline S.NO & Name of journal & $\begin{array}{l}\text { \# of } \\
\text { studies }\end{array}$ & $\begin{array}{l}\text { ERA } \\
\text { rank }\end{array}$ & $\begin{array}{l}\text { Impact } \\
\text { factor }\end{array}$ \\
\hline 1 & $\begin{array}{l}\text { 'Information and Management' } \\
\text { https://www.journals.elsevier.com/information-and-management/ }\end{array}$ & 5 & $A^{*}$ & 2.163 \\
\hline 2 & $\begin{array}{l}\text { 'International Journal of Production Economics' } \\
\text { https://www.journals.elsevier.com/international-journal-of-production-economics }\end{array}$ & 5 & A & 2.782 \\
\hline 3 & $\begin{array}{l}\text { 'Journal of International Management' } \\
\text { https://www.journals.elsevier.com/journal-of-international-management/ }\end{array}$ & 4 & B & 1.982 \\
\hline 4 & $\begin{array}{l}\text { 'The Journal of Strategic Information Systems' } \\
\text { https://www.journals.elsevier.com/the-journal-of-strategic-information-systems/ }\end{array}$ & 3 & A & 2.595 \\
\hline 5 & $\begin{array}{l}\text { 'Omega' } \\
\text { https://www.journals.elsevier.com/omega/ }\end{array}$ & 2 & A & 3.962 \\
\hline 6 & $\begin{array}{l}\text { 'Human Resource Management Review' } \\
\text { https://www.journals.elsevier.com/human-resource-management-review }\end{array}$ & 2 & A & 2.236 \\
\hline 7 & $\begin{array}{l}\text { 'IEEE Transactions on Engineering Management' } \\
\text { http://ieeexplore.ieee.org/xpl/aboutJournal.jsp?punumber=17 }\end{array}$ & 2 & A & 1.454 \\
\hline 8 & $\begin{array}{l}\text { 'Information Systems Frontiers' } \\
\text { https://link.springer.com/journal/10796 }\end{array}$ & 2 & B & 1.450 \\
\hline 9 & $\begin{array}{l}\text { 'International Journal of Project Management' } \\
\text { https://www.journals.elsevier.com/international-journal-of-project-management/ }\end{array}$ & 2 & A & 2.885 \\
\hline
\end{tabular}

Table 9 and 10 indicate that most of the studies are selected from a very high ranked journal and conference, which an unblemished signal of the thoroughness and quality of data sources included in the study. The included 75 papers were published in 47 different venues. Out of 47, we have (35) $46.6 \%$ different journals and $12(25.5 \%)$ different conference venue. Nine journals and two conferences have a count greater than 2 as shown in Table 9 and 10, respectively. HICSS and ICGSE are the top conferences for publishing work on SF and practices in SOP as they have 31.8\% (7 papers) and 22.7\% (5 papers) of the overall included papers published respectively. 'Information and Management' and 'International Journal of Production Economics' are the top journals with a count equal to $5(22.7 \%)$ each. It should be noted that $52 \%$ (39 papers) were published in 11 ( 9 Journals and 2 conferences) venues while the rest 48\% (36 papers) was published in 36 (26 Journals and 10 conferences) venues.

\subsection{Distribution of Studies by Authors}

Table 11 shows the top authors in our study. The criteria used for top authors was count $>2$ paper. Willcocks have published four papers in the selected papers. The authors have a citation greater than one thousand except the two authors Lahiri and Goo, which is also an indication of the quality of the studies. Table 11 will help the researcher, who wants to know about the researcher working in the field.

Table 11. Top Authors in Results of SLR

\begin{tabular}{cllccc}
\hline \hline \multirow{2}{*}{ S.NO } & \multicolumn{2}{c}{ Name of author } & \multirow{2}{*}{ \# of studies } & Published papers & $\begin{array}{c}\text { Citation } \\
\text { count }\end{array}$ \\
\cline { 2 - 3 } & Last Name & First Name & & 333 & 6835 \\
$\mathbf{1}$ & Willcocks & Leslie & 4 & 10 & 185 \\
$\mathbf{2}$ & Lahiri & Indrajit & 2 & 29 & 1025 \\
$\mathbf{3}$ & Kedia & Ben & 2 & 30 & 1467 \\
$\mathbf{4}$ & Kern & Thomas & 2 & 82 & 1419 \\
$\mathbf{5}$ & Lee & Jaenam & 2 & 30 & 477 \\
$\mathbf{6}$ & Goo & Jahyun & 2 & 140 & 2071 \\
$\mathbf{7}$ & Xu & Yan & 2 & 140 & 2071 \\
$\mathbf{8}$ & Yeh & Chunghsing & 2 & & \\
\hline \hline
\end{tabular}

\section{Limitations of the Study}

By using SLR procedure, we extracted data about practices for SFs in SOP, but how valid are our findings are? Related to internal validity ever first threat to be, for any particular study they have not explicitly 
mentioned the cause to report practices for implementing SOP factors. We are unable to independently control this threat. Regarding threats to external validity, in many studies such as case studies, empirical studies and self-reported experience reports may have a propensity to report particular kinds of practices for implementing SFs in SOP. There may be a chance of publication bias in these studies. To lessen the researcher's prejudice, at every step of the SLR, we have conducted the inter-rater reliability tests. Though, impossibility in our research is that every paper is not possible to check by the secondary reviewer. To cope with this we take two authors as a primary reviewer, in order to double check each extracted paper. We do not claim that we have included all digital libraries, so executing our SLR process; it is possible to miss some relevant paper. The first reason is abundant papers on partnership and outsourcing. And the second reason is the unavailability of access to every digital library because of limited resources. However, the included digital libraries are sufficient for the synthesis of results in our study. According to other academics investigator like [48], [54], [56] using SLR as a method for data collection, this is not a methodical faux pas.

\section{Conclusion and Future Direction}

A good number individual's research works have been conducted in the field of outsourcing relationships for finding practices to implement success factors. But no, SLR procedure has been carried out for the documentation of practices in SOP in general and to group the practices in model form in a systematic and collective way in particular. The paper at hand, present results of the one phase of a proposed study in form of frequency analysis. The study protocol is presently in the execution phase. We welcome empirical inquiries on this subject. This will sanction our results and also trajectory vicissitudes in approaches to SOP accomplishments over time. For future work, from the outcomes of current SLR, we have noted the below milestone:

- The solutions for SOP factors will be further authenticated using first-hand studies with practitioners engaged in outsourcing industries.

- The solutions in SOP from client viewpoints will be investigated.

- It will also be investigated that why some practice are used in Europe and South America while other in Asia.

- It will also be checked out that why some practices are reported through questionnaire survey while other through case studies or interview.

Our upcoming work will focus, on the development of SOP framework. This paper presented only one milestone of the proposed frame work SOPM [57], the identification of practices for implementing SOP success factors through SLR.

\section{Appendix}

Table 19. List of Finally Selected Papers. The Conference Papers are Indicated by Italic Style

\begin{tabular}{|c|c|c|c|c|c|c|}
\hline ID & Author(s) & Venue & Title & $\begin{array}{l}\text { J. Vol \& I } \\
\text { Conf. Loc }\end{array}$ & Pages & Year \\
\hline \#1 & Lacity, Khan, Willcocks & $\begin{array}{l}\text { 'The Journal of } \\
\text { Strategic } \\
\text { Information Systems' }\end{array}$ & $\begin{array}{l}\text { 'A review of the IT } \\
\text { outsourcing literature: } \\
\text { Insights for practice' }\end{array}$ & $\begin{array}{l}V=18 \\
\& I=3\end{array}$ & $130-146$ & 2009 \\
\hline$\# 2$ & Hsu, Liou & $\begin{array}{l}\text { 'Journal of Air } \\
\text { Transport } \\
\text { Management' }\end{array}$ & $\begin{array}{l}\text { 'An outsourcing provider } \\
\text { decision model for the } \\
\text { airline industry' }\end{array}$ & $\begin{array}{c}V=28 \& \\
I=1\end{array}$ & $40-46$ & 2013 \\
\hline \#3 & Rohde & $\begin{array}{l}\text { 'International } \\
\text { Journal of } \\
\text { Accounting } \\
\text { Information Systems' }\end{array}$ & $\begin{array}{l}\text { 'IS/IT outsourcing practices } \\
\text { of small-and medium-sized } \\
\text { manufacturers' }\end{array}$ & $\begin{array}{c}V=5 \& \\
I=4\end{array}$ & $429-451$ & 2004 \\
\hline
\end{tabular}




\begin{tabular}{|c|c|c|c|c|c|c|}
\hline$\# 4$ & Handley, Benton & $\begin{array}{l}\text { 'Journal of } \\
\text { operations } \\
\text { management' }\end{array}$ & $\begin{array}{l}\text { 'Unlocking the business } \\
\text { outsourcing process model' }\end{array}$ & $\begin{array}{l}V=27 \\
\& I=5\end{array}$ & $344-361$ & 2009 \\
\hline$\# 5$ & Mukherjee, Gaur, Datta & $\begin{array}{l}\text { 'Journal of } \\
\text { International } \\
\text { Management' }\end{array}$ & $\begin{array}{l}\text { 'Creating value through } \\
\text { offshore outsourcing: An } \\
\text { integrative framework' }\end{array}$ & $\begin{array}{c}V=19 \& \\
I=4\end{array}$ & $377-389$ & 2013 \\
\hline$\# 6$ & Lahiri, Kedia & $\begin{array}{l}\text { 'Journal of } \\
\text { International } \\
\text { Management' }\end{array}$ & $\begin{array}{l}\text { 'The effects of internal } \\
\text { resources and partnership } \\
\text { quality on firm performance: } \\
\text { An examination of Indian } \\
\text { BPO providers' }\end{array}$ & $\begin{array}{l}V=15 \\
\& I=2\end{array}$ & $209-224$ & 2009 \\
\hline$\# 7$ & Sharma & $\begin{array}{l}\text { 'The International } \\
\text { Information \& } \\
\text { Library Review' }\end{array}$ & $\begin{array}{l}\text { 'Exploring best practices in } \\
\text { public private partnership } \\
\text { (PPP) in e-Government } \\
\text { through select Asian case } \\
\text { studies' }\end{array}$ & $\begin{array}{c}V=39 \& \\
I=3\end{array}$ & $203-210$ & 2007 \\
\hline$\# 8$ & Gallear, Ghobadian, Chen & $\begin{array}{l}\text { 'International } \\
\text { Journal of } \\
\text { Production } \\
\text { Economics' }\end{array}$ & $\begin{array}{l}\text { 'Corporate responsibility, } \\
\text { supply chain partnership } \\
\text { and performance: An } \\
\text { empirical examination' }\end{array}$ & $\begin{array}{c}V=140 \& \\
I=1\end{array}$ & $83-91$ & 2012 \\
\hline$\# 9$ & Betz, Oberweis, Stephan & $\begin{array}{l}\text { '5th IEEE } \\
\text { International } \\
\text { Conference on Global } \\
\text { Software } \\
\text { Engineering' }\end{array}$ & $\begin{array}{l}\text { 'Knowledge transfer in IT } \\
\text { offshore outsourcing projects: } \\
\text { An analysis of the current } \\
\text { state and best practices' }\end{array}$ & $\begin{array}{l}\text { Princeton, } \\
\text { USA }\end{array}$ & $330-335$ & 2010 \\
\hline$\# 10$ & Hahn, Gold & $\begin{array}{l}\text { Journal of Business } \\
\text { Research }\end{array}$ & $\begin{array}{l}\text { Resources and governance } \\
\text { in "base of the pyramid" } \\
\text { partnerships: Assessing } \\
\text { collaborations between } \\
\text { businesses and non-business } \\
\text { actors }\end{array}$ & $\begin{array}{l}V=67 \\
\& I=7\end{array}$ & $1321-1333$ & 2014 \\
\hline \#11 & Youn, Yang, Hong, Park & $\begin{array}{l}\text { 'Journal of Cleaner } \\
\text { Production' }\end{array}$ & $\begin{array}{l}\text { 'Strategic supply chain } \\
\text { partnership, environmental } \\
\text { supply chain management } \\
\text { practices, and performance } \\
\text { outcomes: an empirical } \\
\text { study of Korean firms' }\end{array}$ & $\begin{array}{c}V=56 \& \\
I=1\end{array}$ & $121-130$ & 2013 \\
\hline$\# 12$ & Mazzola, Perrone & $\begin{array}{l}\text { 'International } \\
\text { Journal of } \\
\text { Production } \\
\text { Economics' }\end{array}$ & $\begin{array}{l}\text { A strategic needs } \\
\text { perspective on operations } \\
\text { outsourcing and other } \\
\text { inter-firm relationships }\end{array}$ & $\begin{array}{c}V=144 \& \\
\quad I=1\end{array}$ & $256-267$ & 2013 \\
\hline$\# 13$ & Kern, Kreijger, Willcocks & $\begin{array}{l}\text { 'The Journal of } \\
\text { Strategic } \\
\text { Information Systems' }\end{array}$ & $\begin{array}{l}\text { 'Exploring ASP as sourcing } \\
\text { strategy: } \\
\text { perspectives, theoretical } \\
\text { for practice' }\end{array}$ & $\begin{array}{l}V=11 \\
\& I=2\end{array}$ & $153-177$ & 2002 \\
\hline$\# 14$ & Lawther, Martin & $\begin{array}{l}\text { 'Journal of } \\
\text { Purchasing and } \\
\text { Supply Management' }\end{array}$ & $\begin{array}{l}\text { 'Innovative practices in } \\
\text { public procurement } \\
\text { partnerships: The case of the } \\
\text { United States' }\end{array}$ & $\begin{array}{c}V=11 \& \\
I=5\end{array}$ & $212-220$ & 2005 \\
\hline$\# 15$ & Tang, Shen, Cheng & $\begin{array}{l}\text { 'International } \\
\text { Journal of Project } \\
\text { Management' }\end{array}$ & $\begin{array}{l}\text { 'A review of studies on public } \\
\text { "private partnership projects } \\
\text { in the construction industry' }\end{array}$ & $\begin{aligned} V & =28 \& I \\
& =7\end{aligned}$ & $683-694$ & 2010 \\
\hline$\# 16$ & Martinsons, Cheung & $\begin{array}{l}\text { 'Information \& } \\
\text { Management' }\end{array}$ & $\begin{array}{l}\text { 'The impact of emerging } \\
\text { practices on IS specialists: } \\
\text { perceptions, attitudes and } \\
\text { role changes in Hong Kong' }\end{array}$ & $\begin{aligned} V & =38 \& I \\
& =3\end{aligned}$ & $167-183$ & 2001 \\
\hline$\# 17$ & Pereira, Anderson & $\begin{array}{l}\text { Journal of World } \\
\text { Business }\end{array}$ & $\begin{array}{l}\text { 'A longitudinal examination } \\
\text { of HRM in a human } \\
\text { resources offshoring (HRO) } \\
\text { organisation operating from } \\
\text { India' }\end{array}$ & $\begin{array}{l}V=47 \\
\& I=2\end{array}$ & $223-231$ & 2012 \\
\hline$\# 18$ & Haralambides, Gujar & $\begin{array}{l}\text { 'Research in } \\
\text { Transportation } \\
\text { Economics' }\end{array}$ & $\begin{array}{l}\text { 'The Indian dry ports sector, } \\
\text { pricing policies and } \\
\text { opportunities for } \\
\text { public-private partnerships' }\end{array}$ & $\begin{aligned} V & =33 \& I \\
& =1\end{aligned}$ & $51-58$ & 2011 \\
\hline
\end{tabular}




\begin{tabular}{|c|c|c|c|c|c|c|}
\hline$\# 19$ & Li, Ragu, Rao & $\begin{array}{l}\text { 'Omega: The } \\
\text { International Journal } \\
\text { of Management } \\
\text { Science' }\end{array}$ & $\begin{array}{l}\text { 'The impact of supply chain } \\
\text { management practices on } \\
\text { competitive advantage and } \\
\text { organisational performance' }\end{array}$ & $\begin{array}{l}V=34 \\
\& I=2\end{array}$ & $107-124$ & 2006 \\
\hline$\# 20$ & Soltani, Wilkinson & $\begin{array}{l}\text { 'International } \\
\text { Journal of Hospitality } \\
\text { Management' }\end{array}$ & $\begin{array}{l}\text { 'What is happening to } \\
\text { flexible workers in the } \\
\text { supply chain partnerships } \\
\text { between hotel housekeeping } \\
\text { departments and their } \\
\text { partner } \\
\text { agencies?' }\end{array}$ & $\begin{aligned} V & =29 \& I \\
& =1\end{aligned}$ & $108-119$ & 2010 \\
\hline$\# 21$ & Ryals, Rogers & 'Business Horizons' & $\begin{array}{l}\text { Holding up the mirror: The } \\
\text { impact of strategic } \\
\text { procurement practices on } \\
\text { account management. }\end{array}$ & $\begin{aligned} V & =49 \& I \\
& =1\end{aligned}$ & $41-50$ & 2006 \\
\hline$\# 22$ & Lepak, Bartol, Erhardt & $\begin{array}{l}\text { 'Human Resource } \\
\text { Management } \\
\text { Review' }\end{array}$ & $\begin{array}{l}\text { 'A contingency framework } \\
\text { for the delivery of HR } \\
\text { practices' }\end{array}$ & $\begin{array}{l}V=15 \\
\& I=2\end{array}$ & $139-159$ & 2005 \\
\hline$\# 23$ & Meng & $\begin{array}{l}\text { International Journal } \\
\text { of Project } \\
\text { 'Management' }\end{array}$ & $\begin{array}{l}\text { The effect of relationship } \\
\text { management on project } \\
\text { performance in construction }\end{array}$ & $\begin{aligned} V & =30 \& I \\
& =2\end{aligned}$ & 188-198 & 2012 \\
\hline$\# 24$ & Terziovski, Morgan & 'Technovation' & $\begin{array}{l}\text { 'Management practices and } \\
\text { strategies to accelerate the } \\
\text { innovation cycle in the } \\
\text { biotechnology industry' }\end{array}$ & $\begin{array}{l}V=26 \\
\& I=5\end{array}$ & $545-552$. & 2006 \\
\hline$\# 25$ & $\begin{array}{c}\text { Bayraktar, Demirbag, Koh, } \\
\text { Tatoglu, Zaim }\end{array}$ & $\begin{array}{l}\text { 'International } \\
\text { Journal of } \\
\text { Production } \\
\text { Economics' }\end{array}$ & $\begin{array}{l}\text { 'A causal analysis of the } \\
\text { impact of information } \\
\text { systems and supply chain } \\
\text { management practices on } \\
\text { operational performance: } \\
\text { evidence from } \\
\text { manufacturing SMEs in } \\
\text { Turkey' }\end{array}$ & $\begin{array}{l}\mathrm{V}=122 \& \\
\quad \mathrm{I}=1\end{array}$ & $133-149$. & 2009 \\
\hline \#26 & Rau & $\begin{array}{l}\text { 'Human Resource } \\
\text { Management } \\
\text { Review' }\end{array}$ & $\begin{array}{l}\text { 'The diffusion of } \mathrm{HR} \\
\text { practices in unions' }\end{array}$ & $\begin{aligned} V= & 22 \& \mathrm{I} \\
= & 1\end{aligned}$ & $27-42$ & 2012 \\
\hline$\# 27$ & Stoel, Muhanna & $\begin{array}{l}\text { 'Information \& } \\
\text { Management' }\end{array}$ & $\begin{array}{l}\text { 'The dimensions } \\
\text { directionality of trust and } \\
\text { their roles in the } \\
\text { development of shared } \\
\text { business and } \\
\text { understanding' }\end{array}$ & $\begin{array}{l}V=49 \\
\& I=5\end{array}$ & $248-256$ & 2012 \\
\hline \#28 & Mason, Leek & $\begin{array}{l}\text { 'Industrial Marketing } \\
\text { Management' }\end{array}$ & $\begin{array}{l}\text { 'Communication practices in } \\
\text { a business relationship: } \\
\text { Creating, relating and } \\
\text { adapting communication } \\
\text { artifacts through time' }\end{array}$ & $\begin{array}{l}V=41 \\
\& I=2\end{array}$ & $319-332$. & 2012 \\
\hline$\# 29$ & $\begin{array}{l}\text { Willcocks, Oshri, } \\
\text { Kotlarsky, Rottman }\end{array}$ & $\begin{array}{l}\text { 'IEEE Transactions } \\
\text { on Engineering } \\
\text { Management' }\end{array}$ & $\begin{array}{l}\text { 'Outsourcing and offshoring } \\
\text { engineering projects: } \\
\text { understanding the value, } \\
\text { sourcing models and } \\
\text { coordination practices' }\end{array}$ & $\begin{array}{c}V=58 \& \\
I=4\end{array}$ & $706-716$ & 2011 \\
\hline$\# 30$ & Gong, Tate, Alborz & $\begin{array}{l}\text { '40th IEEE Annual } \\
\text { Hawaii International } \\
\text { Conference on System } \\
\text { Sciences' }\end{array}$ & $\begin{array}{l}\text { 'Managing the outsourcing } \\
\text { marriage to achieve success' }\end{array}$ & $\begin{array}{l}\text { Waikoloa, } \\
\text { USA }\end{array}$ & $\begin{array}{c}239 c- \\
239 c\end{array}$ & 2007 \\
\hline$\# 31$ & Gewald, Helbig & $\begin{array}{l}\text { '39th IEEE Annual } \\
\text { Hawaii International } \\
\text { Conference on System } \\
\text { Sciences' }\end{array}$ & $\begin{array}{ll}\text { 'A governance } & \text { model for } \\
\text { managing } & \text { outsourcing } \\
\text { partnerships: a view from } \\
\text { practice' }\end{array}$ & $\begin{array}{l}\text { Kauai, } \\
\text { USA }\end{array}$ & $194 c-194 c$ & 2006 \\
\hline \#32 & $\begin{array}{l}\text { Bannerman, Hossain, } \\
\text { Jeffery }\end{array}$ & $\begin{array}{l}\text { '45th IEEE Annual } \\
\text { Hawaii International } \\
\text { Conference on System } \\
\text { Sciences' }\end{array}$ & $\begin{array}{l}\text { 'Scrum practice mitigation of } \\
\text { global software development } \\
\text { coordination challenges: A } \\
\text { distinctive advantage' }\end{array}$ & $\begin{array}{l}\text { Mau, } \\
\text { Hawaii, } \\
\text { USA }\end{array}$ & $5309-5318$ & 2012 \\
\hline
\end{tabular}




\begin{tabular}{|c|c|c|c|c|c|c|}
\hline$\# 33$ & $\begin{array}{l}\text { Prikladnicki, Audy, } \\
\text { Damian, De Oliveira }\end{array}$ & $\begin{array}{l}\text { 'Second IEEE } \\
\text { International } \\
\text { Conference on Global } \\
\text { Software } \\
\text { Engineering' }\end{array}$ & 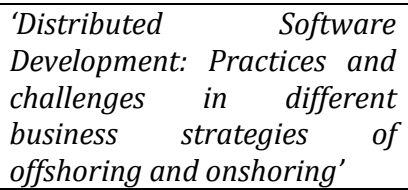 & $\begin{array}{l}\text { Munich, } \\
\text { Germany }\end{array}$ & $262-274$ & 2007 \\
\hline \#34 & Kakola & $\begin{array}{l}\text { '41st IEEE Annual } \\
\text { Hawaii International } \\
\text { Conference on System } \\
\text { Sciences' }\end{array}$ & $\begin{array}{l}\text { 'Best practices for } \\
\text { international eSourcing of } \\
\text { software products and } \\
\text { services' }\end{array}$ & $\begin{array}{l}\text { Waikoloa, } \\
\text { USA }\end{array}$ & $17-17$ & 2008 \\
\hline \#35 & Kess, Torkko, Phusavat & $\begin{array}{l}\text { '29th IEEE } \\
\text { International } \\
\text { Conference on } \\
\text { Information } \\
\text { Technology } \\
\text { Interfaces' }\end{array}$ & $\begin{array}{l}\text { 'Knowledge transfer for } \\
\text { effective } \\
\text { relationships' }\end{array}$ & $\begin{array}{l}\text { Cavtat, } \\
\text { Croatia }\end{array}$ & $69-74$ & 2007 \\
\hline$\# 36$ & Saunders, Chiasson & $\begin{array}{l}\text { '42nd IEEE Annual } \\
\text { Hawaii International } \\
\text { Conference on System } \\
\text { Sciences' }\end{array}$ & $\begin{array}{lr}\text { 'Using } & \text { Knowledge } \\
\text { Management } & \text { Systems to } \\
\text { Structure } & \text { Knowledgeable } \\
\text { Practices' } & \end{array}$ & $\begin{array}{l}\text { Waikoloa, } \\
\text { USA }\end{array}$ & $1-10$ & 2009 \\
\hline$\# 37$ & Jalil, Hanif & $\begin{array}{l}\text { '2nd IEEE } \\
\text { International } \\
\text { Conference on } \\
\text { Computer Science } \\
\text { and Informatio' }\end{array}$ & $\begin{array}{l}\text { 'Improving management of } \\
\text { outsourced software projects } \\
\text { in Pakistan' }\end{array}$ & $\begin{array}{l}\text { Beijing, } \\
\text { China }\end{array}$ & $524-528$ & 2009 \\
\hline$\# 38$ & Boden, Nett, Wulf & $\begin{array}{l}\text { Second IEEE } \\
\text { International } \\
\text { Conference Global } \\
\text { Software Engineering }\end{array}$ & $\begin{array}{lrr}\begin{array}{l}\text { Coordination } \\
\text { distributed }\end{array} & \text { practices in } \\
\text { development } & \text { software } \\
\text { enterprises } & & \text { small } \\
\end{array}$ & $\begin{array}{l}\text { Munich, } \\
\text { Germany }\end{array}$ & $235-246$ & 2007 \\
\hline \#39 & Vijayamma, David & $\begin{array}{l}\text { '18th IEEE } \\
\text { International } \\
\text { Requirements } \\
\text { Engineering } \\
\text { Conference' }\end{array}$ & $\begin{array}{lr}\text { 'Enhancing } & \text { customer } \\
\text { partnership } & \text { through } \\
\text { Requirements Framework' }\end{array}$ & $\begin{array}{l}\text { Sydney, } \\
\text { Australia }\end{array}$ & $337-342$ & 2010 \\
\hline$\# 40$ & $\begin{array}{c}\text { Gopal, Espinosa, Gosain, } \\
\text { Darcy }\end{array}$ & $\begin{array}{l}\text { 'IEEE Transactions } \\
\text { on Engineering } \\
\text { Management' }\end{array}$ & $\begin{array}{l}\text { 'Coordination and } \\
\text { performance in global } \\
\text { software service delivery: } \\
\text { the vendor's perspective' }\end{array}$ & $\begin{array}{l}V=58 \\
\& I=4\end{array}$ & $772-785$ & 2011 \\
\hline$\# 41$ & Forbath, Brooks, Dass & $\begin{array}{l}\text { 'Third IEEE } \\
\text { International } \\
\text { Conference on Global } \\
\text { Software } \\
\text { Engineering' }\end{array}$ & $\begin{array}{l}\text { 'Beyond cost reduction: Using } \\
\text { collaboration to increase } \\
\text { innovation in global software } \\
\text { development projects' }\end{array}$ & $\begin{array}{l}\text { Bangalore, } \\
\text { India }\end{array}$ & $205-209$ & 2008 \\
\hline$\# 42$ & Hofner, Mani & $\begin{array}{l}\text { 'Second IEEE } \\
\text { International } \\
\text { Conference on Global } \\
\text { Software Engineerin' }\end{array}$ & $\begin{array}{l}\text { 'TAPER: A generic framework } \\
\text { for establishing an offshore } \\
\text { development center' }\end{array}$ & $\begin{array}{l}\text { Munich, } \\
\text { Germany }\end{array}$ & $162-172$ & 2007 \\
\hline$\# 43$ & Goles, Chin & $\begin{array}{l}\text { 'The DATA BASE for } \\
\text { Advances in } \\
\text { Information Systems' }\end{array}$ & $\begin{array}{lr}\text { Information } & \text { systems } \\
\text { outsourcing } & \text { relationship } \\
\text { factors: } & \text { detailed } \\
\text { conceptualization and initial } \\
\text { evidence. }\end{array}$ & $\begin{array}{c}V=36 \& \\
I=4\end{array}$ & $47-67$ & 2005 \\
\hline \#44 & Kern, Willcocks & $\begin{array}{l}\text { European Journal of } \\
\text { Information Systems }\end{array}$ & $\begin{array}{l}\text { Exploring relationships in } \\
\text { information } \begin{array}{l}\text { technology } \\
\text { outsourcing: The interaction } \\
\text { approach' }\end{array}\end{array}$ & $\begin{array}{l}V=11 \\
\& I=1\end{array}$ & $3-19$ & 2002 \\
\hline$\# 45$ & Wang, Lu, Zhang & $\begin{array}{l}\text { 'Journal of Zhejiang } \\
\text { University SCIENCE' }\end{array}$ & $\begin{array}{l}\text { 'Software outsourcing risk } \\
\text { management: establishing } \\
\text { outsource evaluation item } \\
\text { systems' }\end{array}$ & $\begin{array}{c}V=7 \& \\
I=6\end{array}$ & $1092-1098$ & 2006 \\
\hline$\# 46$ & Ee, Halim, Ramayah & 'Service Business' & $\begin{array}{l}\text { 'The effects of partnership } \\
\text { quality on business process } \\
\text { outsourcing success in } \\
\text { Malaysia: key users } \\
\text { perspective' }\end{array}$ & $\begin{array}{l}V=7 \\
\& I=2\end{array}$ & $227-253$ & 2013 \\
\hline
\end{tabular}




\begin{tabular}{|c|c|c|c|c|c|c|}
\hline$\# 47$ & Lee, Huynh, Hirschheim & $\begin{array}{l}\text { Information Systems } \\
\text { Frontiers }\end{array}$ & $\begin{array}{l}\text { An integrative model of trust } \\
\text { on IT outsourcing: } \\
\text { Examining a bilateral } \\
\text { perspective }\end{array}$ & $\begin{array}{l}V=10 \\
\& I=2\end{array}$ & $145-163$ & 2008 \\
\hline$\# 48$ & Goo & $\begin{array}{l}\text { 'Information Systems } \\
\text { Frontiers' }\end{array}$ & $\begin{array}{l}\text { 'Structure of service level } \\
\text { agreements (SLA) in IT } \\
\text { outsourcing: The construct } \\
\text { and its measurement' }\end{array}$ & $\begin{array}{c}V=12 \& \\
I=2\end{array}$ & $185-205$ & 2010 \\
\hline$\# 49$ & Han, Kauffman, Nault & $\begin{array}{l}\text { 'Information } \\
\text { Technology and } \\
\text { Management' }\end{array}$ & $\begin{array}{lr}\text { 'Relative } & \text { importance, } \\
\text { specific investment and } \\
\text { ownership in } \\
\text { interorganisational systems' }\end{array}$ & $\begin{array}{l}V=9 \\
\& I=3\end{array}$ & $181-200$ & 2008 \\
\hline$\# 50$ & Aris, Arshad, Mohamed & $\begin{array}{l}\text { 'International } \\
\text { Symposium on } \\
\text { Information } \\
\text { Technology' }\end{array}$ & $\begin{array}{l}\text { 'Risk management practices } \\
\text { in IT outsourcing projects' }\end{array}$ & $\begin{array}{l}\text { Kuala } \\
\text { Lumpur, } \\
\text { Malaysia }\end{array}$ & $1-8$ & 2008 \\
\hline \#51 & Kedia, Lahiri & $\begin{array}{l}\text { 'Journal of } \\
\text { International } \\
\text { Management' }\end{array}$ & $\begin{array}{l}\text { 'International outsourcing of } \\
\text { services: A partnership } \\
\text { model' }\end{array}$ & $\begin{array}{l}V=13 \& \\
I=1\end{array}$ & $22-37$ & 2007 \\
\hline$\# 52$ & Beulen, Ribbers & $\begin{array}{l}\text { '35th IEEE Annual } \\
\text { Hawaii International } \\
\text { Conference on System } \\
\text { Sciences' }\end{array}$ & $\begin{array}{l}\text { 'Managing an IT-outsourcing } \\
\text { partnership in Asia. Case } \\
\text { study: the relationship } \\
\text { between a global outsourcing } \\
\text { company and its global IT } \\
\text { services supplier' }\end{array}$ & $\begin{array}{l}\text { Big Island, } \\
\text { USA }\end{array}$ & $3122-3131$ & 2002 \\
\hline$\# 53$ & Herath, Kishore & $\begin{array}{l}\text { 'Information Systems } \\
\text { Management' }\end{array}$ & $\begin{array}{l}\text { 'Offshore outsourcing: risks, } \\
\text { challenges, and potential } \\
\text { solutions' }\end{array}$ & $\begin{array}{l}V=26 \\
\& I=4\end{array}$ & $312-326$ & 2009 \\
\hline \#54 & $\begin{array}{c}\text { Kinnula,Seppanen,Warsta, } \\
\text { Vilminko }\end{array}$ & $\begin{array}{l}\text { '40th IEEE Annual } \\
\text { Hawaii International } \\
\text { Conference on System } \\
\text { Sciences' }\end{array}$ & $\begin{array}{l}\text { 'The Formation and } \\
\text { Management of a Software } \\
\text { Outsourcing Partnership } \\
\text { Process' }\end{array}$ & $\begin{array}{l}\text { Waikoloa, } \\
\text { USA }\end{array}$ & $240-240$ & 2007 \\
\hline$\# 55$ & Dhar, Balakrishnan & $\begin{array}{l}\text { 'Journal of Global } \\
\text { Information } \\
\text { Management' }\end{array}$ & $\begin{array}{l}\text { 'Risks, benefits, } \\
\text { challenges in global IT } \\
\text { outsourcing' }\end{array}$ & $\begin{array}{c}V=14 \& \\
I=3\end{array}$ & $39-69$ & 2006 \\
\hline \#56 & Lane, Lum & $\begin{array}{l}\text { 'Australasian Journal } \\
\text { of Information } \\
\text { Systems' }\end{array}$ & $\begin{array}{l}\text { 'Examining client } \\
\text { perceptions of partnership } \\
\text { quality and the relationships } \\
\text { between its dimensions in } \\
\text { an IT outsourcing } \\
\text { relationship' }\end{array}$ & $\begin{array}{l}V=17 \\
\& I=1\end{array}$ & $47-76$ & 2010 \\
\hline \#57 & Goo, Kishore, Rao & $\begin{array}{l}\text { '10th Americas } \\
\text { Conference on } \\
\text { Information Systems' }\end{array}$ & $\begin{array}{l}\text { 'Managing IT outsourcing } \\
\text { relationships using service } \\
\text { level agreements (SLAs): A } \\
\text { multi-dimensional fit } \\
\text { approach' }\end{array}$ & $\begin{array}{l}\text { New York, } \\
\text { USA }\end{array}$ & $3514-3519$ & 2004 \\
\hline \#58 & Yang, Fu, Zuo & $\begin{array}{l}\text { '7th international } \\
\text { conference on } \\
\text { Electronic commerce' }\end{array}$ & $\begin{array}{l}\text { 'The integration mechanism } \\
\text { of IT } \quad \text { outsourcing } \\
\text { partnership' }\end{array}$ & $\begin{array}{l}\text { Xi'an, } \\
\text { China }\end{array}$ & $801-803$ & 2005 \\
\hline$\# 59$ & Mao, Lee, Deng & $\begin{array}{l}\text { 'Information \& } \\
\text { Management' }\end{array}$ & $\begin{array}{l}\text { 'Vendors' perspectives on } \\
\text { trust and control in offshore } \\
\text { information systems } \\
\text { Outsourcing' }\end{array}$ & $\begin{array}{c}V=54 \& \\
I=7\end{array}$ & $482-492$ & 2008 \\
\hline$\# 60$ & Teo & $\begin{array}{l}\text { 'International } \\
\text { Journal of } \\
\text { Information } \\
\text { Management' }\end{array}$ & $\begin{array}{l}\text { 'Knowledge management in } \\
\text { client "vendor partnerships' }\end{array}$ & $\begin{array}{l}V=32 \\
\& I=5\end{array}$ & $451-458$ & 2012 \\
\hline \#61 & Barthelemy, Geyer & $\begin{array}{l}\text { 'Information \& } \\
\text { Management' }\end{array}$ & $\begin{array}{l}\text { 'An empirical investigation of } \\
\text { IT outsourcing versus } \\
\text { quasi-outsourcing in France } \\
\text { and Germany' }\end{array}$ & $\begin{array}{c}V=42 \& \\
I=4\end{array}$ & $533-542$ & 2005 \\
\hline$\# 62$ & $\mathrm{Xu}, \mathrm{Yeh}$ & $\begin{array}{l}\text { 'Omega : The } \\
\text { International Journal } \\
\text { of Management } \\
\text { Science' }\end{array}$ & $\begin{array}{l}\text { 'An integrated approach to } \\
\text { evaluation and planning of } \\
\text { best practices' }\end{array}$ & $\begin{array}{l}V=40 \\
\& I=1\end{array}$ & $65-78$ & 2012 \\
\hline
\end{tabular}




\begin{tabular}{|c|c|c|c|c|c|c|}
\hline \#63 & $X u, Y e h$ & $\begin{array}{l}\text { 'Third IEEE } \\
\text { International Joint } \\
\text { Conference on } \\
\text { Computational } \\
\text { Science and } \\
\text { Optimization' }\end{array}$ & $\begin{array}{l}\text { 'An optimal best practice } \\
\text { selection approach' }\end{array}$ & $\begin{array}{l}\text { Anhui, } \\
\text { China }\end{array}$ & $242-246$ & 2010 \\
\hline \#64 & Wagner, Scott, Galliers & $\begin{array}{l}\text { 'Information and } \\
\text { Organisation' }\end{array}$ & $\begin{array}{l}\text { 'The creation of 'best } \\
\text { practice' software: Myth, } \\
\text { reality and ethics' }\end{array}$ & $\begin{array}{c}V=16 \& \\
I=3\end{array}$ & $251-275$ & 2006 \\
\hline \#65 & Teagarden, Meyer, Jones & $\begin{array}{l}\text { 'Organisational } \\
\text { Dynamics' }\end{array}$ & $\begin{array}{l}\text { 'Knowledge Sharing Among } \\
\text { High-Tech MNCs in China } \\
\text { and India: Invisible Barriers, } \\
\text { Best Practices and Next } \\
\text { Steps' }\end{array}$ & $\begin{array}{l}V=37 \\
\& I=2\end{array}$ & $190-202$ & 2008 \\
\hline \#66 & $\begin{array}{c}\text { Thompson, Teo, } \\
\text { Bhattacherjee }\end{array}$ & $\begin{array}{l}\text { 'Information \& } \\
\text { Management' }\end{array}$ & $\begin{array}{l}\text { 'Knowledge transfer and } \\
\text { utilization in IT outsourcing } \\
\text { partnerships: A preliminary } \\
\text { model of antecedents and } \\
\text { outcomes' }\end{array}$ & $\begin{array}{c}V=51 \\
\& I=2014\end{array}$ & $177-186$ & 2014 \\
\hline$\# 67$ & Oshri, Kotlarsky, Gerbasi & $\begin{array}{l}\text { 'Journal of Strategic } \\
\text { Information Systems' }\end{array}$ & $\begin{array}{l}\text { 'Strategic innovation } \\
\text { through outsourcing: The } \\
\text { role of relational and } \\
\text { contractual governance' }\end{array}$ & $\begin{array}{c}V=24 \\
\& I=2015\end{array}$ & $203-216$ & 2015 \\
\hline \#68 & Xiaowei Zhu & $\begin{array}{l}\text { 'Transportation } \\
\text { Research Part E' }\end{array}$ & $\begin{array}{l}\text { 'Managing the risks of } \\
\text { outsourcing: Time, quality } \\
\text { and correlated costs' }\end{array}$ & $\begin{array}{l}V=90 \\
\& I=2016\end{array}$ & $121-133$ & 2015 \\
\hline$\# 69$ & $\begin{array}{c}\text { Schoenherr, Narayanan, } \\
\text { Narasimhan }\end{array}$ & $\begin{array}{l}\text { 'International } \\
\text { Journal of } \\
\text { Production } \\
\text { Economics' }\end{array}$ & $\begin{array}{l}\text { 'Trust formation in } \\
\text { outsourcing relationships: A } \\
\text { social exchange Theoretic } \\
\text { perspective' }\end{array}$ & $\begin{array}{l}V=169 \\
\& I=2015\end{array}$ & $401-412$ & 2015 \\
\hline$\# 70$ & $\begin{array}{c}\text { Gasparenienea, } \\
\text { Vasauskaiteb }\end{array}$ & $\begin{array}{l}\text { '19th International } \\
\text { Scientific } \\
\text { Conference; } \\
\text { Economics and } \\
\text { Management' }\end{array}$ & $\begin{array}{l}\text { 'Analysis of the criterions of } \\
\text { outsourcing contracts in } \\
\text { public and private sectors: } \\
\text { review of the scientific } \\
\text { literature' }\end{array}$ & $\begin{array}{l}\text { Riga, } \\
\text { Latvia }\end{array}$ & $274-279$ & 2014 \\
\hline$\# 71$ & Han, Bae & $\begin{array}{l}\text { 'International } \\
\text { Journal of } \\
\text { Production } \\
\text { Economics' }\end{array}$ & $\begin{array}{l}\text { 'Internalization of } R \& D \\
\text { outsourcing: An empirical } \\
\text { study' }\end{array}$ & $\begin{array}{l}V=150 \\
\& I=2014\end{array}$ & $58-73$ & 2014 \\
\hline$\# 72$ & Søderberg, Krishna, Bjørn & $\begin{array}{l}\text { 'Journal of } \\
\text { International } \\
\text { Management' }\end{array}$ & $\begin{array}{l}\text { 'Global Software } \\
\text { Development: Commitment, } \\
\text { Trust and Cultural } \\
\text { Sensitivity in Strategic } \\
\text { Partnerships' }\end{array}$ & $\begin{array}{l}V=19 \\
\& I=2013\end{array}$ & $347-361$ & 2013 \\
\hline$\# 73$ & Vorontsova, Rusa & $\begin{array}{l}\text { 'Procedia } \\
\text { Technology' }\end{array}$ & $\begin{array}{l}\text { 'Determinants of IT } \\
\text { Outsourcing Relationships: A } \\
\text { Recipient - Provider } \\
\text { Perspective' }\end{array}$ & $\begin{array}{l}V=16 \\
\& I=2014\end{array}$ & $588-597$ & 2014 \\
\hline \#74 & Jones & $\begin{array}{l}\text { 'Asset Management } \\
\text { Conference' }\end{array}$ & $\begin{array}{l}\text { 'Customising the partnership } \\
\text { - standardising the delivery: } \\
\text { driving mutual benefits in } \\
\text { outsource } \\
\text { partnerships' }\end{array}$ & $\begin{array}{l}\text { London, } \\
\text { UK }\end{array}$ & $1-3$ & 2014 \\
\hline$\# 75$ & Kusyk & $\begin{array}{l}\text { 'Information } \\
\text { Technologies in } \\
\text { Innovation Business' }\end{array}$ & $\begin{array}{l}\text { State-Private Partnership in } \\
\text { the Field of Social } \\
\text { Reproduction: Facility } \\
\text { Management' }\end{array}$ & $\begin{array}{l}\text { Kharkiv, } \\
\text { Ukraine }\end{array}$ & $72-75$ & 2015 \\
\hline
\end{tabular}

\section{Acknowledgment}

We are thankful to all members of Beijing Key Lab of Petroleum and Data Mining at China University of Petroleum, Beijing. The authors also pay attributes to a research group, SERG, at the University of Malakand for their important feedback during the review session. 


\section{References}

[1] Lee, J. N., \& Kim, Y. G. (2005). Understanding outsourcing partnership: A comparison of three theoretical perspectives. IEEE Transactions on Engineering Management, 52(1), 43-58.

[2] Kelly, M. J., Schaan, J. L., \& Joncas, H. (2002). Managing alliance relationships: Key challenges in the early stages of collaboration. Research \& Development Management, 32(1), 11-22.

[3] Bamford, J., Ernst, D., \& Fubini, D. G. (2004). Launching a world-class joint venture. Harvard Business Review, 82(2), 90-100.

[4] Kemppainen, K., \& Vepsalainen, A. P. J. (2003). Trends in industrial supply chains and networks. International Journal of Physical Distribution \& Logistics Management, 33(8), 701-719.

[5] Garciacanal, E., Duarte, C. L., Criado, J. R., \& Llaneza, A. V. (2002). Accelerating international expansion through global alliances: A typology of cooperative strategies. Journal of World Business, 37(2), 91-107.

[6] Rothaermel, F. T., \& Boeker, W. (2007). Old technology meets new technology: Complementarities, similarities, and alliance formation. Strategic Management Journal, 29(1), 47-77.

[7] Venkatraman, N., \& Loh, L. (1994). The shifting logic of the IS organization: From technical portfolio to relationship portfolio. Information Strategy, 10(1), 5-11, 1994.

[8] Kinnula, M., \& Seppanen, V. (2003). Information technology requirements in an outsourcing partnership. Proceedings of the Frontiers of E-Business Research (pp. 493-503). Finland: Tampere.

[9] Moe, N. B., Smite, D., Hanssen, G. K., \& Barney, H. T. (2014). From offshore outsourcing to insourcing and partnerships: Four failed outsourcing attempts. Empirical Software Engineering, 19(5), 1225-1258.

[10] Kishore, R., Rao, H. R., Nam, K., Rajagopalan, S., \& Chaudhury, A. (2003). A relationship perspective on IT outsourcing. Communications of the ACM, 46(12), 86-92.

[11] Srinivasan, R., \& Brush, T. H. (2006). Supplier performance in vertical alliances: The effects of self-enforcing agreements and enforceable contracts. Organization Science, 17(4), 436-452.

[12] Kinnula, M., Seppanen, V., Warsta, J. V., \& Vilminko, S. (2007). The formation and management of a software outsourcing partnership process. Proceedings of the 40th Hawaii International Conference on System Sciences (pp-240-240).

[13] Ali, S., \& Khan, S. U. (2014). Critical success factors for software outsourcing partnership (SOP): A systematic literature review. Proceedings of the 9th International Conference on Global Software Engineering (pp-154-162).

[14] Bowersox, D., Closs, D., \& Stank, T. (2003). How to master cross-enterprise collaboration. Supply Chain Management Review, 7(4), 18-27.

[15] Verwaal, E., \& Hesselmans, M. (2004). Drivers of supply network governance: An explorative study of the dutch chemical industry. European Management Journal, 22(4), 442-451.

[16] Parkhe, A. (1993). Messy research, methodological predispositions, and theory development in international joint ventures. Academy of Management review, 18(2), 227-268.

[17] Lane, M. S., \& Lum, W. H. (2011). Examining client perceptions of partnership quality and the relationships between its dimensions in an IT outsourcing relationship. Australasian Journal of Information Systems, 17(1), 47-76.

[18] Ring, P. S., \& Van de Ven, A. H. (1994). Developmental processes of cooperative inter-organizational relationships. Academy of Management Review, 19(1), 90-118.

[19] Anderson, J. C., \& Narus, J. A. (1990). A model of distributor firm and manufacturer firm working partnerships. Journal of Marketing, 54(1), 42-58.

[20] Anderson, E., \& Weitz, B. (1989). Determinants of continuity in conventional industrial channel dyads. Marketing Science, 8(4), 310-323.

[21] Dwyer, F. R., Schurr, P. H., \& Oh, S. (1987). Developing buyer-seller relationships. The Journal of 
marketing, 51(2), 11-27.

[22] Levinthal, D. A., \& Fichman, M. (1988). Dynamics of inter-organizational attachments: Auditor-client relationships. Administrative Science Quarterly, 33(3), 345-369.

[23] Kedia, B. L., \& Lahiri, S. (2007). International outsourcing of services: A partnership model. Journal of International Management, 13(1), 22-37.

[24] Lee, J. N., Huynh, M. Q., Chi-wai, K. R., \& Pi, S. M. (2000). The evolution of outsourcing research: What is the next issue? Proceedings of the 33rd IEEE Hawaii International Conference on System Sciences. (pp. 1-10).

[25] Yang, B., Fu, H., \& Zuo, M. (2005). The integration mechanism of IT outsourcing partnership. Proceedings of the 7th International Conference on Electronic Commerce (pp. 801-803).

[26] Sun, S., Lin, T., \& Sun, P. (2002). The factors influencing information systems outsourcing partnership - A study integrating case study and survey research methods. Proceedings of the the 35th Hawaii International Conference on System Sciences (pp. 2810-2819).

[27] Assmann, D. P. (2003). Toward partnership in software subcontracting. Computer in Industry, 54(2), 137-150.

[28] Henderson, J. C., \& Venkatraman, N. (1992). Strategic Alignment: A Model for Organizational Transformation through Information Technology. New York: Oxford University Press.

[29] Lee, J. N. (2001). The impact of knowledge sharing, organizational capability and partnership quality on IS outsourcing success. Information \& Management, 38(5), 323-335.

[30] Lee, J. N., \& Kim, Y. G. (1999). Effect of partnership quality on is outsourcing success: Conceptual framework and empirical validation. Journal of Management Information Systems, 15(4), 29-61.

[31] Li, E. l. (2013). Study of the decision-making model of outsourcing service provider selection. International Journal of $u$ - and e-Service of Science and Technology, 6(2), 1-10.

[32] Lai, Y. H. (2016). The factors affecting partnership quality of hospital information systems outsourcing of PACS. Proceeding of the International Conference on Industrial, Engineering and Other Applications of Applied Intelligent Systems (pp. 484-492).

[33] Roses, L. S. K. (2013). Strategic partnership building in it offshore outsourcing: Institutional elements for a banking ERP system licensing. Journal of Information Systems and Technology Management, 10(1), 61-80.

[34] Ylitalo, J., Eerikki, M., \& Ziegler, K. (2004). Building Mutuality and Trust in Strategic Partnership. Meaning of Early Stages in Relationship Formation: A Case Study. Finland: Helsinki University of Technology BIT Research Centre, Espoo,

[35] Ellram, L. M., \& Edis, O. R. (1996). A case study of successful partnering implementation. Journal of Supply Chain Management, 32(4), 20-28.

[36] Tuten, T. L., \& Urban, D. J. (2001). An expanded model of business-to-business partnership formation and success. Industrial Marketing Management, 30(2), 149-164.

[37] Kinnula, M., \& Juntunen, S. (2005). A case study of success factors in outsourcing partnership formation and management. Proceedings of the 21st IMP-Conference.

[38] Hussein, M. (2007). A Survey of Outsourcing of Training Services by Commercial Banks in Kenya. New York: University of Nairobi Library.

[39] Flemming, R., \& Low, G. (2007). Information systems outsourcing relationship model. Australasian Journal of Information Systems, 14(2), 95-112.

[40] Garousi, V., Petersen, K., \& Ozkan, B. (2016). Challenges and best practices in industry-academia collaborations in software engineering: A systematic literature review. Information \& Software Technology, 79(2016), 106-127. 
[41] Bocij, P., \& Hickie, S. (2008). Business Information Systems: Technology, Development and Management for the E-business, Pearson education (2nd ed.).

[42] Piltan, M., \& Sowlati, T. (2016). Multi-criteria assessment of partnership components. Expert Systems with Applications, 64(2016), 605-617.

[43] Foote, D. (2004). Recipe for offshore outsourcing failure: Ignore organization, people issues. $A B A$ Banking Journal, 96(9), 56-59.

[44] Ali, S., \& Khan, S. U. (2016). Software outsourcing partnership model: An evaluation framework for vendor organizations. The Journal of Systems and Software, 117 (2016), 402-425.

[45] Khalfan, A. (2013). A case analysis of business process outsourcing project failure profile and implementation problems in a large organisation of a developing nation. Business Process Management Journal, 9(6), 745-759.

[46] Dyer, J. H., Kale, P., \& Singh, H. (2001). How to make strategic alliances work. MIT Sloan Management Review, 42(4), 37-43.

[47] Kitchenham, B. C., \& Stuart. (2007). Guidelines for Performing Systematic Literature Review in Software Engineering (No. 01). U. K: Keele University.

[48] Khan, S. U., Niazi, M., \& Rashid, A. (2011). Factors influencing clients in the selection of offshore software outsourcing vendors: An exploratory study using a systematic literature review. Journal of Systems and Software, 84(2011), 686-699.

[49] Venkatraman, N. V. (2004). Offshoring without guilt. MIT Sloan Management Review, 45(3), 14-16.

[50] Kirkegaard, J. F. (2005). Outsourcing and Offshoring: Pushing the European Model over the Hill, Rather than Off the Cliff! (Report No. 05-1). Institute for International Economics.

[51] Butterworth, G., Kuchler, M., \& Westdijk, S. (2013). Outsourcing in Europe: An in-depth review of drivers, risks and trends in the European outsourcing market. Retrieved from http://www.ey.com/Publication/vwLUAssets/Outsourcing_in_Europe_2013/\$FILE/EY-outsourcing-su rvey.pdf

[52] Trewin, D. (2014). Australian Small Business Key Statistics and Analysis. p. 109.

[53] Zahedi, M., Shahin, M., \& Babar, M. A. (2016). A systematic review of knowledge sharing challenges and practices in global software development. International Journal of Information Management, 36(6), 995-1019.

[54] Verner, J. M., Brereton, O. P., Kitchenham, B. A., Turner, M., \& Niazi, M. (2014). Risks and risk mitigation in global software development: A tertiary study. Information and Software Technology, 56(1), 54-78.

[55] Khan, S. U., \& Ali, S. (2015). Empirical investigation of success factors for establishing software. Proceedings of the Pakistan Academy of Sciences.

[56] Ali, S., \& Khan, S. U. (2014). Software outsourcing partnership (SOP): A systematic literature review protocol with preliminary results. International Journal of Hybrid Information Technology, 7(4), 377-392.

[57] Ali, S., \& Khan, S. U. (2014). Software outsourcing partnership model. Science International Journal Lahore, 26(4), 1437-1441.

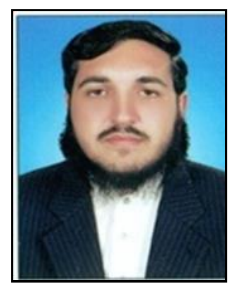

Sikandar Ali is a Ph.D student at the China University of Petroleum, Beijing under the supervision of Professor Dr. Li Hongqi. He has earned his M.Phil. software engineering degree under the research supervision of Dr. Siffat Ullah Khan at the University of Malakand, Lower Dir, Pakistan. He also taught at University of Swat, Pakistan for three years. His research interest lies in software outsourcing partnership, empirical software engineering, systematic literature review, requirements engineering, green computing, intelligent 
computing, agile software development and global software engineering. Till date, he has published a number of articles in well reputed International conferences and Journals.

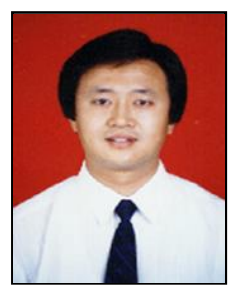

Li Hongqi is a professor and Ph.D advisor in the Computer Technology Department at the China University of Petroleum, Beijing. Li's research interests are swarm intelligence, particle swarm, optimization, intelligent information processing, software engineering, data mining, and big data mining. Till date, Li supervise more than 100 master and Ph.D students. He is the controller of the Beijing key lab of petroleum and data mining.

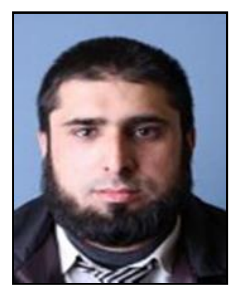

Siffat Ullah Khan is assistant professor of Computer Science \& IT Department, University of Malakand, Pakistan. He holds a Ph.D in computer science from Keele University, UK. He is the founder of SERG at the University of Malakand. Siffat Ullah Khan with a gold medal (Dr. M. N. Azam Prize 2015) for his research achievements in the field of computer (software). He has been the head of the Department of Software Engineering at the University of Malakand for 3 years. He is currently leading software engineering research group (SERG-UOM) at the University of Malakand. Till date, he has published almost 100 articles in well reputed international conferences and journals. His research interest includes software outsourcing, empirical software engineering, systematic literature review, software metrics, green computing, cloud computing, requirements engineering and green computing.

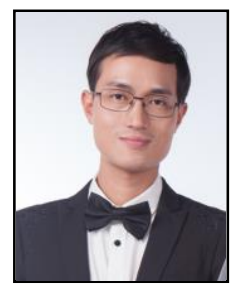

Yang Zhongguo was a graduate student of information and computational science at Harbin Institute of Technology in 2010. He is now in pursuit of Ph.D degree in artificial intelligence from China University of Petroleum (Beijing). His research interests include data mining, paramer selection algorithm, genetic algorithm, and intelligent information processing and application. 